\title{
A Pool of Postnatally Generated Interneurons Persists in an Immature Stage in the Olfactory Bulb
}

\author{
Nuria Benito, ${ }^{1}$ Elodie Gaborieau, ${ }^{2}$ Alvaro Sanz Diez, ${ }^{1}$ Seher Kosar, ${ }^{1}$ Louis Foucault, ${ }^{2}$ Olivier Raineteau, ${ }^{2}$ \\ and ${ }^{-D i d i e r}$ De Saint Jan ${ }^{1}$ \\ ${ }^{1}$ Institut des Neurosciences Cellulaires et Intégratives, Centre National de la Recherche Scientifique, Université de Strasbourg, 67084 Strasbourg, France, \\ and 2Univ Lyon, Université Claude Bernard Lyon 1, Inserm, Stem Cell and Brain Research Institute U1208, 69500 Bron, France
}

Calretinin (CR)-expressing periglomerular (PG) cells are the most abundant interneurons in the glomerular layer of the olfactory bulb. They are predominately generated postnatally from the septal and dorsal subventricular zones that continue producing them well into adulthood. Yet, little is known about their properties and functions. Using transgenic approaches and patch-clamp recording in mice of both sexes we show that $\mathrm{CR}(+)$ PG cells of both septal and dorsal origin have homogeneous morphological and electrophysiological properties. However, unlike other PG cells, these axonless neurons express a surprisingly small repertoire of voltage-activated channels and do not fire or fire at most a single and often small action potential. Moreover, they are not innervated by olfactory sensory neurons and receive little synaptic inputs from mitral or tufted cells at excitatory synapses where NMDA receptors predominate. These membrane and synaptic properties, that resemble those of newborn immature neurons not yet integrated in the network, persist over time and limit the recruitment of $\mathrm{CR}(+) \mathrm{PG}$ cells by afferent inputs that strongly drive local network activity. Together, our results show that postnatally generated CR $(+)$ PG cells continuously supply a large pool of neurons with unconventional properties. These data also question the contribution of $\mathrm{CR}(+) \mathrm{PG}$ cells in olfactory bulb computation.

Key words: calretinin; neurogenesis; olfactory bulb; periglomerular cell

\section{Significance Statement}

Calretinin-expressing PG cells are by far the most abundant interneurons in the glomerular layer of the olfactory bulb. They are continuously produced during postnatal life, including adulthood, from neural stem cells located in the subventricular zones. Surprisingly, unlike other postnatally generated newborn neurons that quickly integrate into preexisting olfactory bulb networks, calretinin-expressing PG cells retain immature properties that limit their recruitment in local network activity for weeks, if not months, as if they would never fully mature. The function of this so far unsuspected pool of latent neurons is still unknown.

\section{Introduction}

GABAergic interneurons constitute the vast majority of all neurons in the olfactory bulb, the first relay for odor processing in the

\footnotetext{
Received May 9, 2018; revised July 31, 2018; accepted Aug. 9, 2018.

Author contributions: N.B., E.G., A.S.-D., S.K., L.F., O.R., and D.D.S.J. edited the paper; D.D.S.J. wrote the first draft of the paper. O.R. and D.D.S.J. designed research; N.B., E.G., A.S.-D., S.K., L.F., O.R., and D.D.S.J. performed research; N.B., E.G., A.S.-D., L.F., O.R., and D.D.S.J. analyzed data; 0.R. and D.D.S.J. wrote the paper.

This work was supported by the Centre National pour la Recherche Scientifique, the Université de Strasbourg and the Agence Nationale pour la Recherche (Grant ANR-12-JSV4-006-01), a fellowship from the Ministère de la Recherche and by a fellowship from the Fonds Paul Mandel pour les Recherches en Neuroscience to A.S.D, and a Grant from the "Programme Avenir Lyon Saint-Etienne". We thank Sophie Reibel-Foisset and the animal facility Chronobiotron (UMS 3415 Centre National pour la Recherche Scientifique and Université de Strasbourg), the Plateforme Imagerie In Vitro-Neuropôle-Strasbourg, Bastien Leclerc, Aline Huber for their technical assistance, and Linda OverstreetWadiche, Cécile Viollet, and members of the laboratory for their advice and support.

The authors declare no competing financial interests.

Correspondence should be addressed to either of the following: Dr. Didier De Saint Jan, Institut des Neurosciences Cellulaires et Intégratives, CNRS UPR 3212, 5 rue Blaise Pascal, 67084 Strasbourg, France, E-mail: desaintjan@inci-cnrs.unistra.fr; or Olivier Raineteau, Univ Lyon, UniversitéClaude Bernard Lyon 1, Inserm, Stem Cell and Brain Research Institute U1208, 69500 Bron, France, E-mail: olivier.raineteau@inserm.fr.
}

brain. As elsewhere in the brain, olfactory bulb interneurons are diverse and the functional implications of this diversity are still partially understood (Burton, 2017). Answering this question requires a systematic analysis of each interneuron subtype, covering their developmental origin, morphology, physiology, and molecular identity. Many studies have focused on granule cells, the most abundant interneurons that make reciprocal dendrodendritic synapses on mitral and tufted cells lateral dendrites. Much less is known about periglomerular (PG) interneurons that exclusively interact with the apical dendrites of mitral and tufted cells.

PG cells surround each glomerulus where mitral and tufted cells receive synaptic inputs from olfactory sensory neurons (OSNs). They are molecularly, morphologically and functionally heterogeneous (McQuiston and Katz, 2001; Hayar et al., 2004;

https://doi.org/10.1523/JNEUROSCl.1216-18.2018

Copyright $\odot 2018$ the authors $\quad 0270-6474 / 18 / 389870-13 \$ 15.00 / 0$ 
Kosaka and Kosaka, 2007; Panzanelli et al., 2007; Parrish-Aungst et al., 2007; Whitman and Greer, 2007; Najac et al., 2015) and the various subtypes have specific spatial and temporal developmental origins (Batista-Brito et al., 2008; X. Li et al., 2011; Weinandy et al., 2011). All known PG cell subtypes continue to be generated during the postnatal period, including adulthood, from specific neural stem cells with different embryonic origins and located in defined microdomains in the walls of the subventricular zone (SVZ; Fiorelli et al., 2015). Calretinin (CR) $(+)$ PG cells are the most abundant PG cell subtype, representing $40-50 \%$ of the whole PG cell population. They are 2-3 times more numerous than other subtypes expressing calbindin (CB), parvalbumin, or tyrosine hydroxylase (TH; Kosaka and Kosaka, 2007; Panzanelli et al., 2007; Parrish-Aungst et al., 2007; Whitman and Greer, 2007). CR(+) PG cells are also the most abundant PG cells generated postnatally. Contrasting with $\mathrm{CB}(+)$ and $\mathrm{TH}(+)$ cells whose production is maximal during embryogenesis and declines after birth, production of $\mathrm{CR}(+) \mathrm{PG}$ cells peaks around birth and continues throughout life (De Marchis et al., 2007; Ninkovic et al., 2007; Batista-Brito et al., 2008; X. Li et al., 2011; Weinandy et al., 2011).

Functionally, PG cells have been classified into two classes: type $1 \mathrm{PG}$ cells that receive direct synaptic inputs from OSNs, and type 2 PG cells that do not. Like $\mathrm{CB}(+) \mathrm{PG}$ cells, dendrites of $\mathrm{CR}(+)$ PG cells avoid compartments of the glomerulus that contain OSN terminals and have therefore been classified as type 2 PG cells (Kosaka and Kosaka, 2007). Consistent with this classification, we recently confirmed that $\mathrm{CR}(+) \mathrm{PG}$ cells do not receive synaptic inputs from OSNs (Najac et al., 2015). Several observations, however, suggest unique properties of $\mathrm{CR}(+) \mathrm{PG}$ cells. For instance, they have different embryonic origins than $\mathrm{CB}(+)$ PG cells (Kohwi et al., 2007) and their development is regulated by specific transcription factors (Waclaw et al., 2006; Kohwi et al., 2007; Qin et al., 2017; Tiveron et al., 2017). They also present distinctive electrical membrane properties (Fogli Iseppe et al., 2016).

We combined transgenic approaches and patch-clamp recording in olfactory bulb slices to examine the origin, intrinsic and synaptic properties of this so far overlooked interneuron subtype. We found that $\mathrm{CR}(+)$ PG cells show a dual spatial origin, i.e., the septal and dorsal SVZ that continue producing them well into adulthood, although at different pace. Despite these distinct origins, $\mathrm{CR}(+) \mathrm{PG}$ cells are homogeneous in term of morphological and electrophysiological properties. Interestingly, $\mathrm{CR}(+)$ PG cells show immature traits which persist over extended periods of time and limit their recruitment in local network firing activity. Instead, we propose that $\mathrm{CR}(+)$ PG cells constitute a pool of latent neurons, possibly representing a previously unsuspected reservoir of plasticity.

\section{Materials and Methods}

Animals. The Rosa ${ }^{\text {YFP }}$ mice express YFP upon Cre recombination (Srinivas et al., 2001; line 006148, The Jackson Laboratory). The CR::EGFP mice express EGFP under the control of the CR promoter (Caputi et al., 2009). The Kv3.1::EYFP mice express EYFP under the control of the Kv3.1 $\mathrm{K}^{+}$channel promoter (Metzger et al., 2002), resulting in EYFP expression in a specific population of PG cells that includes all CBexpressing PG cells (Najac et al., 2015). Male and female mice were used indifferently.

Acute slice preparation. All experimental procedures conformed to the French Ministry and local ethics committee (CREMEAS) guidelines on animal experimentation. Transgenic mice of different ages were decapitated and the olfactory bulbs removed and immersed in ice-cold solution containing the following (in mM): $83 \mathrm{NaCl}, 26.2 \mathrm{NaHCO}_{3}, 1 \mathrm{NaH}_{2} \mathrm{PO}_{4}$,
$2.5 \mathrm{KCl}, 3.3 \mathrm{MgSO}_{4}, 0.5 \mathrm{CaCl}_{2}, 70$ sucrose, and $22 \mathrm{D}$-glucose, pH 7.3 (300 $\mathrm{mOsm} / \mathrm{L}$ ), bubbled with $95 \% \mathrm{O}_{2} / 5 \% \mathrm{CO}_{2}$. Horizontal olfactory bulb slices $(300 \mu \mathrm{m})$ were cut using a Microm HM $650 \mathrm{~V}$ vibratome in the same solution. The slices were incubated for $30 \mathrm{~min}$ at $34^{\circ} \mathrm{C}$ and then stored until use at room temperature in artificial CSF (ACSF) containing the following (in mM): $125 \mathrm{NaCl}, 25 \mathrm{NaHCO}_{3}, 2.5 \mathrm{KCl}, 1.25 \mathrm{NaH}_{2} \mathrm{PO}_{4}, 1$ $\mathrm{MgCl}_{2}, 2 \mathrm{CaCl}_{2}$, and $25 \mathrm{D}$-glucose, continuously oxygenated with $95 \%$ $\mathrm{O}_{2} / 5 \% \mathrm{CO}_{2}$.

Electrophysiology. Experiments were conducted at $32-34^{\circ} \mathrm{C}$ under an upright microscope (SliceScope, Scientifica) with differential interference contrast optics. Loose cell-attached recordings (15-100 M $\Omega$ seal resistance) were made with pipettes filled with ACSF. OSN axons bundles projecting inside a given glomerulus were stimulated using a theta pipette filled with ACSF as previously described (Najac et al., 2011). The electrical stimulus $(100 \mu \mathrm{s})$ was delivered using a Digitimer DS3. Most wholecell recordings were made with pipettes (3-6 M $\Omega$ ) filled with (in $\mathrm{mM}$ ): $135 \mathrm{~K}$-gluconate, $2 \mathrm{MgCl} 2,0.025 \mathrm{CaCl} 2,1$ EGTA, $4 \mathrm{Na}$-ATP, $0.5 \mathrm{Na}$ GTP, and 10 HEPES, pH 7.3 (280 Osm/L). Atto 594 fluorescent dye (5 $\mathrm{mm}$, Sigma-) was routinely added to the internal solution to confirm the glomerular projection of the recorded cell. Voltages indicated in the paper were corrected for the junction potential $(-15 \mathrm{mV})$. The tip of the recording pipette was systematically coated with wax and we used the capacitance neutralization of the amplifier to reduce the capacitance of the pipette. In current-clamp recordings, a constant hyperpolarizing current was injected to maintain the cell at a potential of $-60 /-70 \mathrm{mV}$. Without any current injected, the membrane potential remained at positive potentials. In voltage-clamp recordings, the access resistance was compensated by $50-80 \%$. Sodium currents were recorded using a Csbased internal solution, containing the following (in $\mathrm{mm}$ ): $120 \mathrm{Cs}$ $\mathrm{MeSO}_{3}, 20$ tetraethylammonium-Cl (TEA), 54-aminopyridine (4-AP), 2 $\mathrm{MgCl}_{2}, 0.025 \mathrm{CaCl}_{2}, 1$ EGTA, $4 \mathrm{Na}$-ATP, $0.5 \mathrm{Na}$-GTP, and 10 HEPES, $\mathrm{pH}$ $7.3(280 \mathrm{Osm} / \mathrm{L},-10 \mathrm{mV}$ junction potential $)$, and in the presence of $\mathrm{CdCl}(100 \mu \mathrm{M}), \mathrm{TEA}(20 \mathrm{~mm})$, and 4-AP (5 mM) in the bath. In whole-cell paired recordings, mitral and tufted cells were recorded with this Csbased internal solution supplemented with 5-10 mM Atto 594 whereas the K-gluconate-based internal solution, supplemented with $10 \mathrm{~mm}$ GABA, was used in PG cells, as previously done (Najac et al., 2015). Finally, a high chloride internal solution containing the following (in $\mathrm{mm}$ ): $120 \mathrm{CsCl}$, $0.1 \mathrm{EGTA}, 4 \mathrm{Na}-\mathrm{ATP}, 0.5 \mathrm{Na}-\mathrm{GTP}, 10$ phosphocreatine, and 10 HEPES (270 Osm/L) was used for recording self-inhibition in PG cells.

Recordings were acquired with a MultiClamp 700B amplifier (Molecular Devices), low-passed filtered at $2-4 \mathrm{kHz}$ and digitized at $10 \mathrm{kHz}$ using the AxoGraph X software (AxoGraph Scientific).

Recording analysis. Data were analyzed using AxoGraph X (AxoGraph Scientific). Current amplitudes were measured as the peak of an average response computed from multiple sweeps. Spike amplitudes were measured between the peak and the most negative voltage reached immediately after the spike. Membrane time constants were obtained from the exponential fit of the voltage deflection caused by a small hyperpolarizing current. Individual spontaneous excitatory (EPSC) or inhibitory (IPSC) currents with amplitude $>5 \mathrm{pA}$ were automatically detected by the AxoGraph X software using a sliding template function. For measuring the AMPA/NMDA ratio, neurons were first voltage-clamped at $-75 \mathrm{mV}$ and their excitatory inputs were evoked with an electrical stimulation in the external plexiform layer (EPL). Stimulation intensity was adjusted to obtain isolated responses. Neurons were then voltage-clamped at $+50 / 60 \mathrm{mV}$ to release the $\mathrm{Mg}^{2+}$ blockade of NMDA receptors and to provide a driving force large enough to record small EPSCs. After a stabilization period of 5-15 min, the NMDA receptor antagonist D-2amino-5-phosphonopentanoic acid (D-AP5; $50 \mu \mathrm{M}$, Abcam) was bath applied to isolate AMPA currents. Isolated AMPA currents were digitally subtracted offline from the total EPSCs to obtain the NMDA currents.

Plasmids. Plasmids pUb-TdTomato plasmid (gift from D. Jabaudon, Université de Genève) and pCAG-CRE (13775, Addgene) were prepared with a PEG-LiCl protocol and used at a concentration of $5 \mu \mathrm{g} / \mu \mathrm{l}$. For electroporation (EPO), plasmids were mixed 1:10 with a contrast solution of fast green $(0.2 \%)$ in sterile PBS. 
Electroporations. EPOs were performed in postnatal day (P)2 pups as described previously (Boutin et al., 2008; Fernández et al., 2011). Briefly, pups were anesthetized in ice and placed on a custom-made support in a stereotaxic rig. Injections were performed at the midpoint of a virtual line traced between the eye and the lambda. A 34 gauge needle attached to a Hamilton syringe was inserted at a depth of $2.5 \mathrm{~mm}$ from the skull surface and $1.5 \mu \mathrm{l}$ of plasmid solution was injected into the lateral ventricle. The accuracy of the injection was verified by the filling of the ventricle with the contrast solution. Successfully injected mice were then subjected to five electrical pulses ( $95 \mathrm{~V}, 50 \mathrm{~ms}$, separated by $950 \mathrm{~ms}$ intervals) using the Super Electroporator NEPA21 type II (Nepa Gene) and tweezer electrodes coated with conductive gel (SIGNAGEL, Parker Laboratories). Electrodes were positioned to target the lateral, dorsal, or septal wall. After EPO, pups were warmed up until they fully recovered and returned to their mother.

BrdU treatments and tissue processing. For analysis of CR(+) PG cells spatial and temporal origin, 5-bromo-2-deoxyuridine (BrdU; SigmaAldrich, B5002) was added in drinking water at a concentration of 1 $\mathrm{mg} / \mathrm{ml}$ supplemented with sucrose at $10 \mathrm{mg} / \mathrm{ml}$ for $15 \mathrm{~d}$ (from P12 to P27), protected from light and changed every $2 \mathrm{~d}$. Animals were killed at $45 \mathrm{~d}$ after EPO. After deep anesthesia with intraperitoneal pentobarbital, mice were transcardially perfused with a Ringer solution and a 4\% paraformaldehyde in $0.1 \mathrm{M}$ PB solution, brains were removed, postfixed for $24 \mathrm{~h}$, and cut with a vibratome (Leica VT1000S). Fifty micrometer coronal sections were collected from the olfactory bulb to the lateral ventricle in series of six and kept at $-20^{\circ} \mathrm{C}$ in antifreeze solution (glucose $15 \%$, sodium azide $0.02 \%$, ethylene glycol $30 \%, \mathrm{~PB} 0.1 \mathrm{M}$ ).

For birth dating of CR(+) PG cells, CR::EGFP transgenic mice (P30) received four intraperitoneal injections of $20 \mathrm{mg} / \mathrm{ml} \mathrm{BrdU}$ in sterile $0.9 \%$ $\mathrm{NaCl}$ solution $(100 \mathrm{mg} / \mathrm{kg}), 2 \mathrm{~h}$ apart. At days 15, 20, 30, 40, 50, and 60 after injection, mice were anesthetized by intraperitoneal injection of a ketamine and xylazine mixture (90 and $100 \mathrm{mg} / \mathrm{kg}$, respectively), and transcardially perfused with $4 \%$ paraformaldehyde diluted in PBS. The brain was removed and postfixed overnight at $4^{\circ} \mathrm{C}$. Horizontal sections of the olfactory bulbs $(30 \mu \mathrm{m})$ were sliced on a vibratome (Leica VT1000S).

Immunostaining. For BrdU staining, free-floating sections were incubated for $1 \mathrm{~h}$ in Triton X-100 (0.2-0.4\% in PBS), pretreated in $1 \mathrm{~N}$ (10 $\left.\min , 37^{\circ} \mathrm{C}\right)$ and $2 \mathrm{~N}\left(20 \mathrm{~min}, 37^{\circ} \mathrm{C}\right) \mathrm{HCl}$, and washed in $0.1 \mathrm{~m}$ borate buffer, $\mathrm{pH} 8.4$ (5-30 min). After rinsing three times with PBS (10 min), sections were incubated in blocking solution containing BSA (2\%) and Triton X-100 $(0.3 \%)$, for $1 \mathrm{~h}$ before incubation with the primary antibodies (Table 1).

For cFos staining, antigen retrieval treatment was performed in $10 \mathrm{~mm}$ citrate buffer, $\mathrm{pH} 6\left(20 \mathrm{~min}, 80^{\circ} \mathrm{C}\right)$. After rinsing three times with Triton $\mathrm{X}-100(0.4 \%$ in PBS), sections were incubated in blocking solution for $2-4 \mathrm{~h}$ at room temperature (BSA $0.25 \%$, Casein, $0.05 \%$, Top block $0.25 \%$ + Triton X-100 0.4\% in PBS) before incubation with the primary antibodies overnight at $4^{\circ} \mathrm{C}$ (Table 1$)$.

Following incubation with primary antibodies, sections were rinsed then incubated $2 \mathrm{~h}$ at room temperature with the corresponding secondary antibody (Table 1). To amplify YFP signal, sections were incubated with a biotinylated secondary antibody followed by streptavidin-DTAF for $45 \mathrm{~min}$. For morphological reconstruction, the tomato signal was amplified with an anti-RFP antibody. Finally, sections were counterstained with DAPI and mounted with Prolong Antifade (ThermoFisher) or Fluoromount (SouthernBiotech) mounting medium.

Quantifications. For the analysis of $\mathrm{CR}(+) \mathrm{PG}$ interneurons neurogenesis and spatial and temporal origin, $\mathrm{YFP}(+)$ cells were counted in the glomerular layer on live images using an epifluorescent microscope (Leica DM5500, objective HCX PL APO 40× 1.25 oil).

For CR::EGFP interneurons origin, 3 animals were analyzed for dorsal and septal EPO, and the number of $\mathrm{CR}(+)$ and $\mathrm{EGFP}(+) \mathrm{PG}$ cells among the Td-Tomato-expressing population analyzed $[>85 \mathrm{Td}$-tomato $(+)$ cells per EPO].

For $\mathrm{CR}(+) / \mathrm{EGFP}(+) \mathrm{PG}$ interneurons birth dating analysis, series of 3 slices ( $3 Z$-stack sections per slice) were analyzed with a confocal microscope (Leica SP5), and the number of $\mathrm{BrdU}(+)$ nuclei located in the glomerular layer counted $(>120 \mathrm{BrdU}(+)$ cells per animal). $\mathrm{BrdU}(+)$
Table 1. Primary and secondary antibodies

\begin{tabular}{llll}
\hline & Species & Concentration & Source (catalog No.) \\
\hline $\begin{array}{llll}\text { Primary antibodies } \\
\text { Anti-BrdU }\end{array}$ & & & \\
Anti-BrdU & Rat & $1: 500$ & ABD Serotech (ABD0030) \\
Anti-calretinin & Rat & $1: 500$ & Abcam Ab6326 \\
Anti-calretinin & Rabbit & $1: 1000$ to 1:2000 & SWANT (7697) \\
Anti-calbindin & Mouse & $1: 2000$ & SWANT (6B3) \\
Anti-cFos & Mouse & $1: 2000$ & SWANT (D28K) \\
Anti-TH & Goat & $1: 50$ & Santa Cruz Biotechnology (Sc-52-G) \\
Anti-GFP & Mouse & $1: 400$ & Millipore (MAB318) \\
Anti-doublecortin & Chicken & $1: 1000$ & JAVES (GFP-1020) \\
Anti-RFP & Goat & $1: 500$ & Santa Cruz Biotechnology (Sc-8066) \\
Secondary antibodies & Rabbit & $1: 1500$ & MBL (PM005) \\
Anti-rat AlexaFluor 555 & & & \\
Anti-rat AlexaFluor 546 & Donkey & $1: 1000$ & ThermoFisher Scientific (A-21434) \\
Anti-mouse AlexaFluor 555 & Donkey & $1: 1000$ & ThermoFisher Scientific (A-11081) \\
Anti-mouse AlexaFluor 647 & Donkey & $1: 1000$ & ThermoFisher Scientific (A-31570) \\
Anti-rabbit AlexaFluor 555 & Donkey & $1: 1000$ & ThermoFisher Scientific (A-31571) \\
Anti-rabbit AlexaFluor 647 & Donkey & $1: 1000$ & ThermoFisher Scientific (A-31572) \\
Anti-rabbit AlexaFluor 633 & Goat & $1: 200$ & ThermoFisher Scientific (A-31573) \\
Anti-goat AlexaFluor 555 & Donkey & $1: 1000$ & ThermoFisher Scientific (A-21070) \\
Anti-chicken biotinylated & Donkey & $1: 1000$ & ThermoFisher Scientific (A-21432) \\
Streptavidin-DTAF & - & $1: 250$ & The Jackson Laboratory (703-065-155) \\
\hline & & & The Jackson Laboratory (016-010-084) \\
\hline
\end{tabular}

cells coexpressing CR and EGFP were independently counted by two experimenters without any stereological procedure.

For cFos analysis, images were taken with a confocal microscope (Leica SP5) using a $40 \times$ objective (HCX PL APO $40 \times 1.25$ oil). cFos-positive nuclei expressing $\mathrm{CR}, \mathrm{CB}$, and $\mathrm{TH}$ in the glomerular layer were quantified ( $>120$ cFos-positive cell per animal; 3 animals per condition). Analysis was focused on cells bordering glomeruli where an intense cFos staining was observed.

For arborization analysis of $\mathrm{CR}(+) \mathrm{PG}$ interneurons, $0.3 \mu \mathrm{m}$ stack images were taken with a confocal microscope (Leica SPE), and 3D neurons reconstruction were performed and analyzed with the software Neurolucida 360 [43 EGFP $(+)$ cells vs 12 EGFP $(-)$, equally distributed between septal and dorsal EPO, i.e., 26 and $29 \mathrm{CR}(+)$ neurons, respectively; 3 mice per EPO]. For a direct comparison with $\mathrm{CB}(+)$ PG interneurons, $\mathrm{CB}(+)$ neurons were reconstructed from three dorsally electroporated mice, as they were consistently absent from septally electroporated ones.

Experimental design and statistical analysis. For each electrophysiology dataset, recordings were made in slices derived from at least four animals. The numbers of cells used for the analysis are indicated in the text. Data are expressed as mean \pm SEM. We used the Student's $t$ test to assess the statistical difference between unpaired sets of data with normal distribution and the nonparametric Wilcoxon-Mann-Whitney rank sum test to assess the statistical difference between unpaired sets of data that did not assume a normal distribution. Statistical significance was determined at the $p<0.05$ and $p$ values are reported in the text.

\section{Results}

\section{CR(+) PG cells from different spatial origin are morphologically homogeneous}

The postnatal SVZ produces distinct subtypes of PG interneurons in a region-dependent manner. We have shown that $\mathrm{CR}(+)$ PG cells originate from the dorsal and septal most regions of the SVZ at birth (Fernández et al., 2011). The temporal dynamic of their postnatal production, however, remains elusive. To address this question, we combined targeted EPO of specific SVZ microdomains with a Cre-lox approach in P2-old Rosa ${ }^{\text {YFP }}$ mice for permanent labeling and fate mapping of neural stem cells located in the lateral, dorsal, and septal aspects of the postnatal SVZ (Fig. $1 A)$. We killed the mice at 1.5 and 3 months and quantified recombined $\mathrm{CR}(+) \mathrm{PG}$ cells expressing the immature neuronal marker doublecortin (DCX) to determine the spatial origin of 


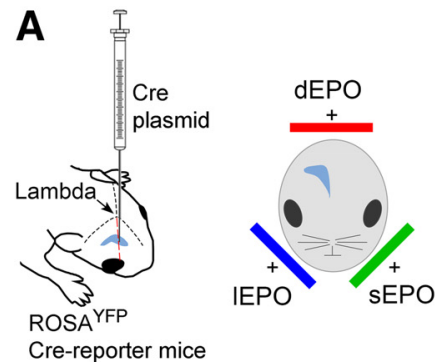

C
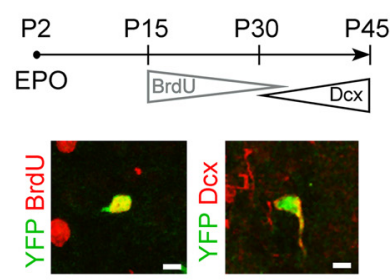

F

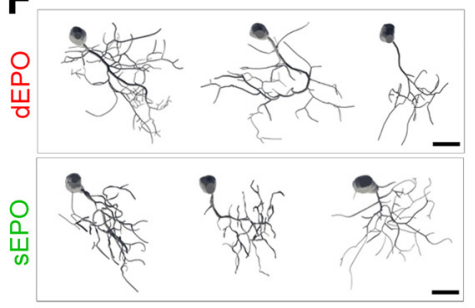

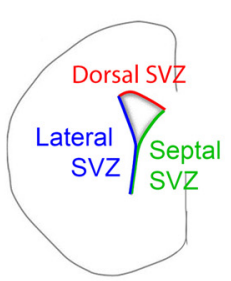

D

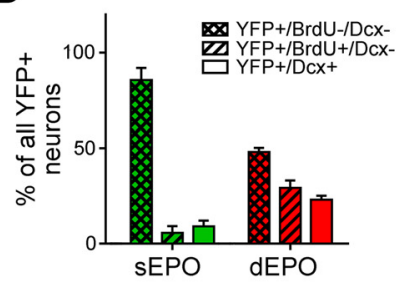

G

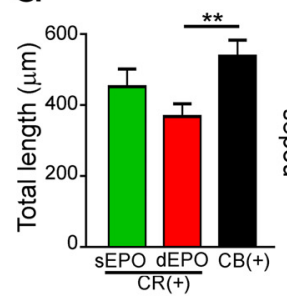

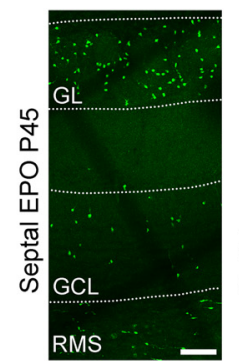
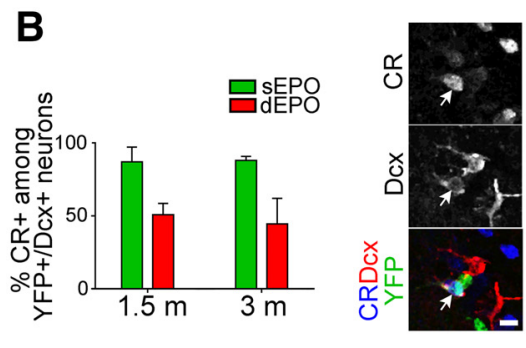

E

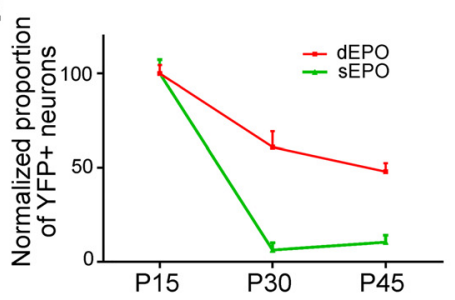

H
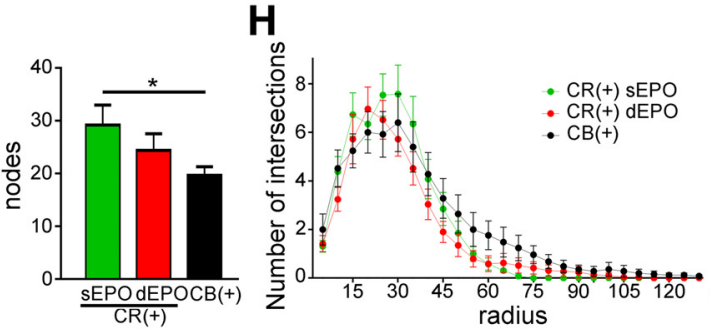

Figure 1. Spatiotemporal origin and morphology of postnatally generated $C R(+) P G$ interneurons. $A$, We modified a previously established targeted EP0 approach for permanent labeling and fate mapping of neural stem cells that reside in defined microdomains of the postnatal SVZ. A plasmid expressing the Cre recombinase was electroporated in dorsal, lateral, and septal SVZ of Rosa YFP Cre-reporter mice allowing the recombination and permanent expression of a YFP in neural stem cells and their progeny. The picture on the right shows the accumulation of YFP $(+)$ cells in the olfactory bulb $45 \mathrm{~d}$ after a septal EPO. Scale bar, $100 \mu \mathrm{m}$. B, Quantification of the fraction of $C R(+)$ PG interneurons among DCX $(+) / Y F P(+)$ PG cells at 1.5 and 3 months reveal their stable spatial origin over time. The number of cells expressing (R was negligible following lateral electroporation, and was not quantified. Scale bar, $5 \mu \mathrm{m}$. $\mathbf{C}$, Long-term fate mapping was combined with immunodetection of BrdU and DCX to discriminate between cohorts of neurons sequentially produced at distinct postnatal times over a period of 1.5 months. Inset, Representative images of YFP( + ) cells expressing BrdU or DCX.Scale bars, $5 \mu \mathrm{m} . \boldsymbol{D}, \boldsymbol{E}$, Quantification of YFP( + ) PG cells born at early (BrdU $-/ D C X-)$, intermediate (BrdU $+/ D C X-)$ and late time (BrdU - /DCX + ) during the first 1.5 months of postnatal life reveals the temporal dynamic of neurogenesis from the septal and dorsal SVZ microdomains. Data were normalized in $\boldsymbol{E}$ for better clarity. $\boldsymbol{F}$, Neurolucida reconstruction of $Y F P(+) / C R(+) P G$ interneurons originating from the dorsal and septal SVZ at $21 \mathrm{~d}$ post-EPO. G, Quantification of dendritic arborization length and number of nodes in $(R(+)$ PG interneurons originating from the dorsal (red) and septal (green) SVZ. Values for $\mathrm{CB}(+) \mathrm{PG}$ cells reconstructed at $21 \mathrm{~d}$ after dorsal EPO are given for comparison. Scale bars, $10 \mu \mathrm{m} .{ }^{*} p<0.05,{ }^{* *} p<0.01$. $\boldsymbol{H}$, Sholl analysis representing the number of dendrite intersections with concentric circles of gradually increasing radius. Cre, Cre recombinase; GL, glomerular layer; GCL, granule cell layer; RMS, rostral migratory stream.

cells generated in the last $2 / 3$ weeks (Fig. $1 B) . \mathrm{CR}(+)$ PG cells constituted the majority of the DCX $(+)$ PG cells derived from the septal and, to a lesser extent, dorsal SVZ $[83.1 \pm 6.2 \%$ and $59.5 \pm 10.3 \%$, respectively, at 1.5 months and $88.3 \pm 2.9 \%$ and $44.7 \pm 17.6 \%$, respectively, at 3 months; $>50 \mathrm{YFP}(+) / \mathrm{DCX}(+)$ cells per EPO in $n=3$ mice at both time points], whereas the lateral SVZ rarely produced CR(+) PG cells. Thus, both the septal and dorsal microdomains remain active in producing $\mathrm{CR}(+)$ PG interneurons in adulthood, in similar proportions as previously observed at birth (Fernández et al., 2011).

We next assessed the temporal dynamic in neurogenic activity of the septal and dorsal SVZ microdomains. We administrated BrdU through drinking water during the second half of the first month of postnatal life, and killed the animals at 1.5 months (Fig. $1 C)$. BrdU and DCX immunodetection allowed us to discriminate early $[\operatorname{BrdU}(-) / \operatorname{DCX}(-)]$, intermediate $[\operatorname{BrdU}(+) / \operatorname{DCX}(-)]$ and late born interneurons $[\mathrm{BrdU}(-) / \mathrm{DCX}(+)]$ among recombined $\mathrm{YFP}(+)$ cells [Fig. $1 C ; n=164 \mathrm{YFP}(+)$ cells in 6 mice for dorsal $\mathrm{EPO} ; n=240 \mathrm{YFP}(+)$ cells in 3 mice for septal EPO]. This analysis revealed a gradual decrease of neurogenesis for both microdomains, which appeared more pronounced for the septal SVZ (Fig. 1D,E). Thus, although CR(+) PG interneurons present a dual origin, the contribution of the septal SVZ declines faster than the contribution of the dorsal SVZ in their generation.
These observations prompted us to investigate possible morphological differences between $\mathrm{CR}(+) \mathrm{PG}$ cells produced by the septal and dorsal SVZ. Individual CR $(+)$ PG cells originating from both SVZ microdomains were reconstructed $21 \mathrm{~d}$ post-EPO (Fig. $1 F$ ) and compared with $\mathrm{CB}(+) \mathrm{PG}$ cells at the same age. All reconstructed cells $[n=26 \mathrm{CR}(+)$ from septal $\mathrm{EPO}, n=29$ $\mathrm{CR}(+)$ and $n=25 \mathrm{CB}(+)$ from dorsal EPO, in $n=3$ mice per condition] had the typical morphology of mature PG cells i.e., no axon and a polarized dendritic tree ramifying within a single glomerulus (Fig. $1 F$ ). Quantitative analysis of dendritic length and number of nodes (Fig. $1 G$ ), as well as a Sholl analysis that measures the number of times the dendrites intersect with consecutive concentric circles (Fig. $1 H$ ) revealed a similarly complex and a rather homogeneous morphology for CR(+) PG cells, independent of their origin $[p>0.05$ for all dorsal/septal CR $(+)$ comparison in Fig. $1 G, H]$. The Sholl analysis also revealed no significant difference between CR and CB-expressing PG cells (Fig. $1 H$ ), although dorsal CR $(+)$ cells had a tendency for shorter dendrites and septal CR $(+)$ cell a tendency for more nodes (Fig. $1 G)$. Thus, $\mathrm{CR}(+) \mathrm{PG}$ cells with distinct spatial origin have largely similar morphologies and, despite small differences that may reflect the morphological immaturity of some cells included in this analysis, resemble $\mathrm{CB}(+) \mathrm{PG}$ cells. 
A
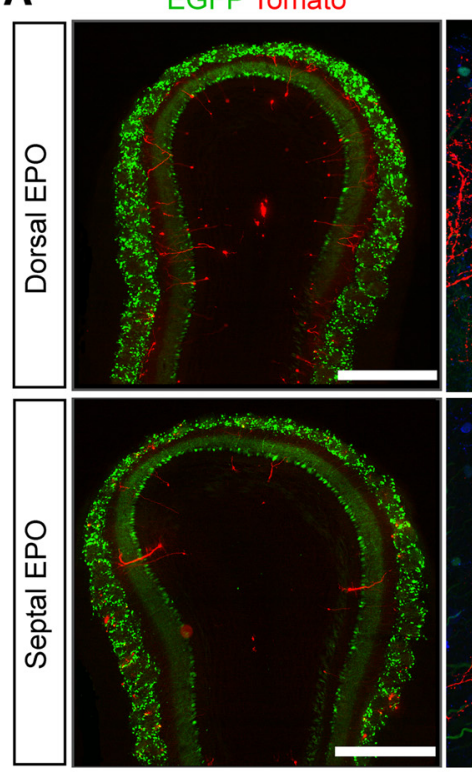
EGFP Tomato

EGFP Tomato CR
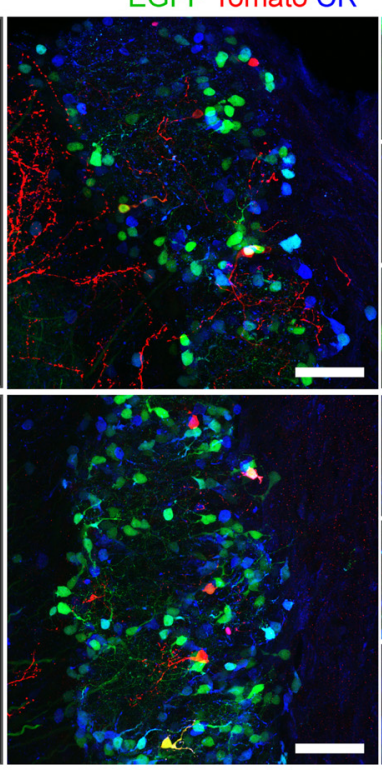

D

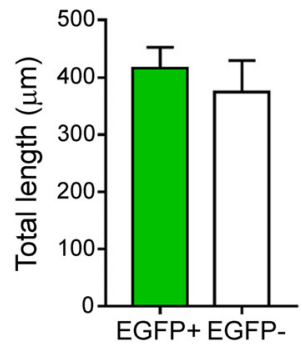

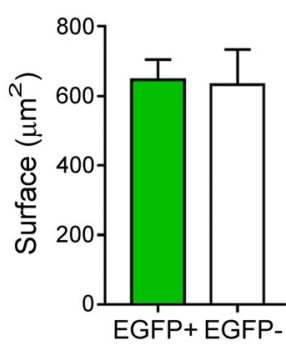

$E G F P+E G F P$

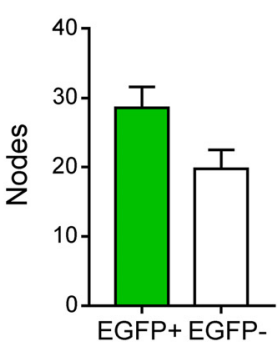

B
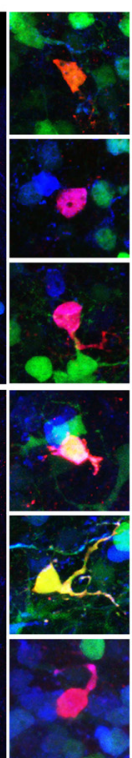

C
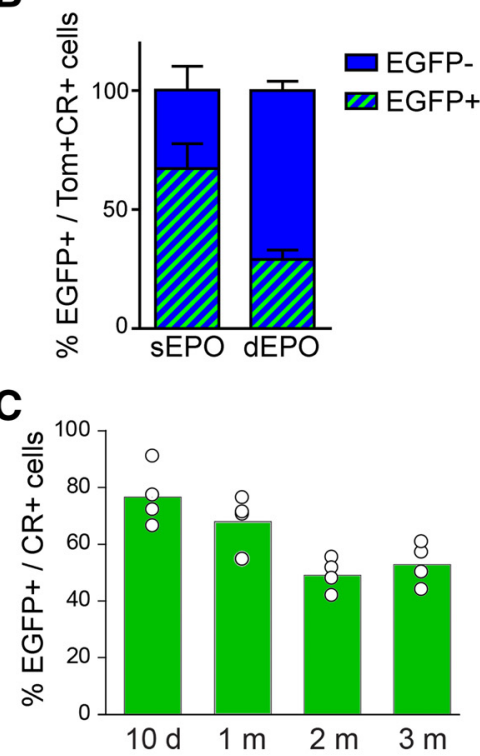
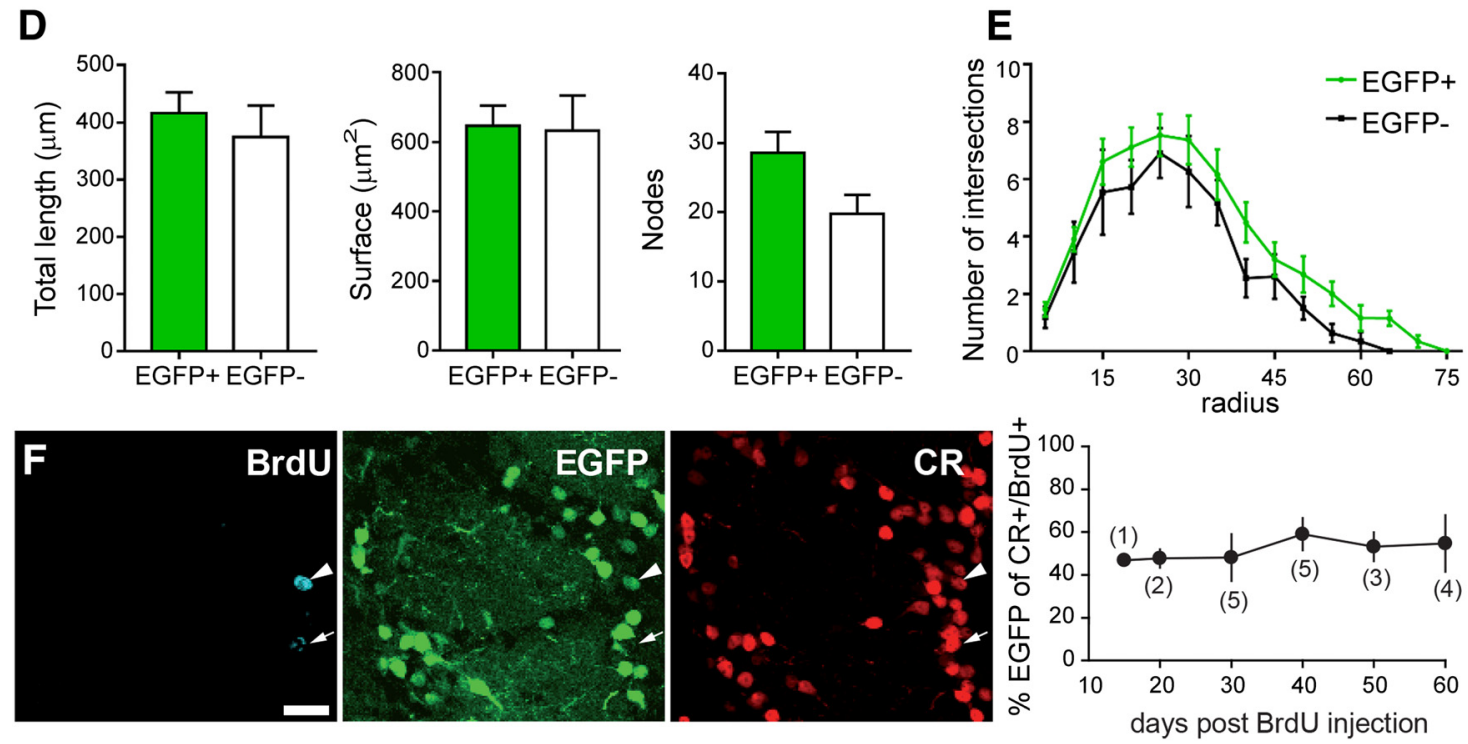

Figure 2. Labeling of a representative population of $C R(+) P G$ interneurons in the $C R: E G F P$ transgenic mice. $A$, Fate mapping of $E G F P(+) / C R(+) P G$ interneurons from dorsal and septal origin by EPO of a tdTomato-expressing plasmid in CR::EGFP transgenic mice. Captions show marker expression by select cells: $\operatorname{Tom}(+) / C R(+)$ appear in orange/yellow, while those also expressing EGFP appear in pink. Scale bars: left, $500 \mu \mathrm{m}$; right, $50 \mu \mathrm{m}$. B, Proportion of $\mathrm{CR}(+)$ PG interneurons expressing EGFP following dorsal and septal EPO. Note that EGFP expression can be observed in both populations of $\mathrm{CR}(+) \mathrm{PG}$ interneurons. C, Percentage of EGFP expression among the $\mathrm{CR}(+) \mathrm{PG}$ population at different postnatal ages. $\boldsymbol{D}$, Neurolucida reconstruction of $\mathrm{EGFP}(+)$ and $\mathrm{EGFP}(-)$ $\operatorname{Tom}(+) / C R(+) P G$ interneurons reveals comparable dendritic arborization length, surface and number of nodes. $\boldsymbol{E}$, Sholl analysis representing the number and distribution of dendrite intersections with concentric circles of gradually increasing radius. $F$, Birth dating of $C R(+) P G$ interneuron demonstrates stable EGFP expression in $(R(+) P G$ interneurons up to $60 \mathrm{~d}$ after their generation. $S$ cale bar, $10 \mu \mathrm{m}$.

\section{CR::EGFP transgenic mice recapitulate the complex} spatiotemporal origin of $\mathrm{CR}(+)$ PG cells

The CR::EGFP transgenic mouse expresses EGFP under the control of the CR promoter (Caputi et al., 2009). In the glomerular layer of the olfactory bulb, EGFP is exclusively expressed in CR(+) PG cells (Najac et al., 2015; Fig. 2A). To assess whether EGFP labels a subpopulation of CR(+) PG cells with a specific origin, we transiently electroporated the septal or dorsal SVZ of CR::EGFP newborn pups with a plasmid encoding tdTomato (Tom; Fig. 2A). Three weeks later, we quantified the fraction of Tom $(+) / C R(+)$ PG cells that also expressed EGFP $(n=69$ and $n=43 \mathrm{Tom}(+) / \mathrm{CR}(+)$ PG cells counted in 3 mice, respectively). We found that both the septal and dorsal SVZ produced
EGFP(+) PG cells, although in different proportion $(67 \pm 10 \%$ and $29 \pm 4 \%$, respectively; Fig. $2 B)$. The number of $\operatorname{EGFP}(+)$ among CR-expressing PG cells slightly decreased from $\sim 80 \%$ at $10 \mathrm{~d}$ to $\sim 50 \%$ in adult mice (Fig. $2 C$ ), possibly reflecting the increasing contribution of the dorsal SVZ to their production or differences in lifespan of $\mathrm{CR}(+) \mathrm{PG}$ cells originating from the two walls. However, reconstructions of individual Tom $(+) / \mathrm{CR}(+)$ cells positive $(n=43)$ or negative $(n=12)$ for EGFP revealed no morphological differences between the two populations ( $p=$ 0.58 for total length and $p=0.91$ for surface; Fig. $2 D, E$ ).

Finally, we conducted a birth dating experiment to determine whether the EGFP labeling also recapitulates the age diversity of $\mathrm{CR}(+)$ PG cells or only transiently labels CR(+) PG cells at a 
A

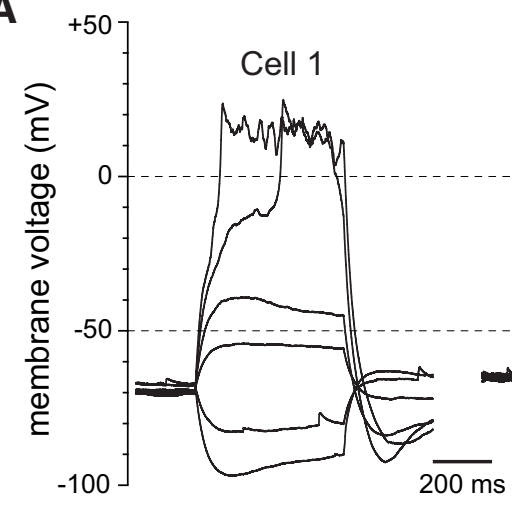

D

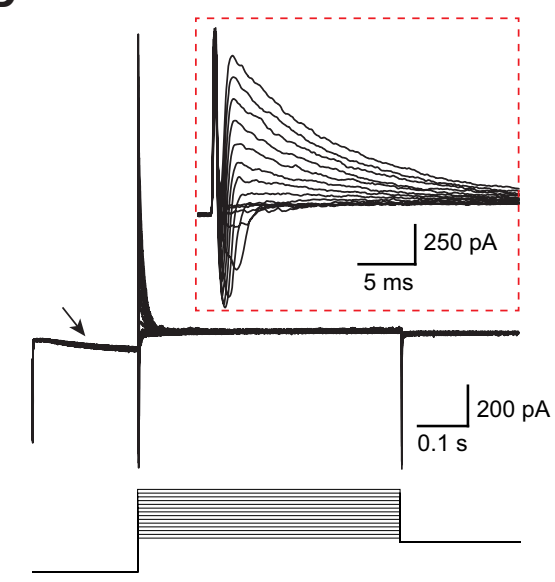

Cell 2
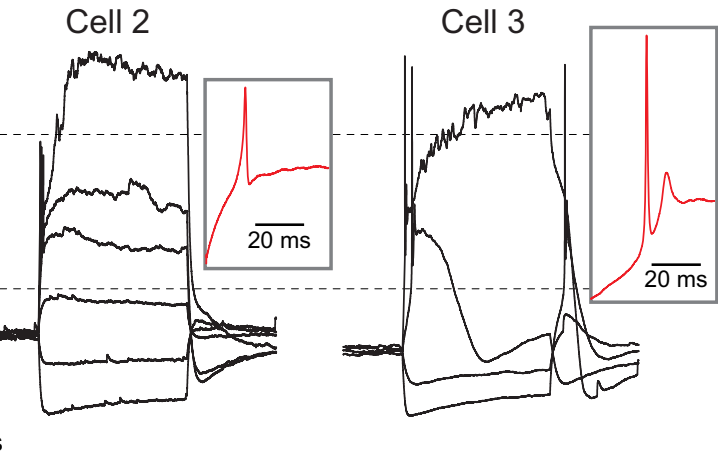

E

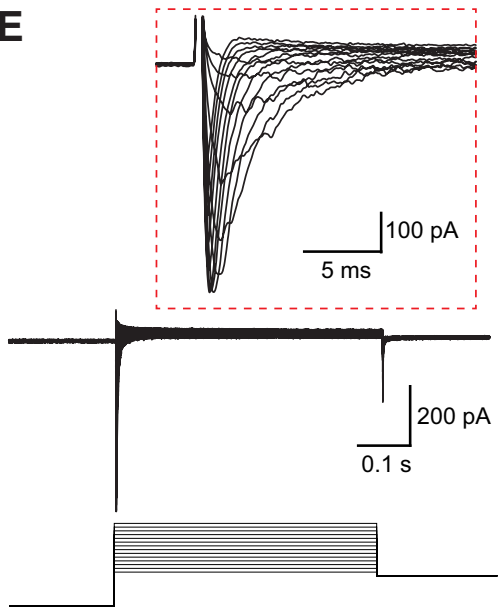

B

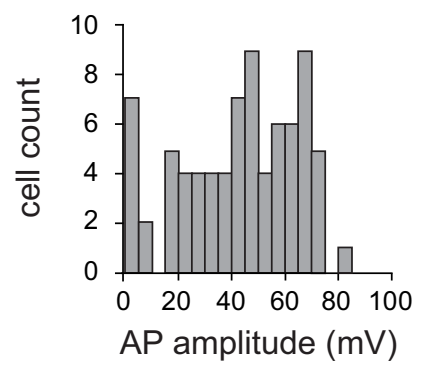

C

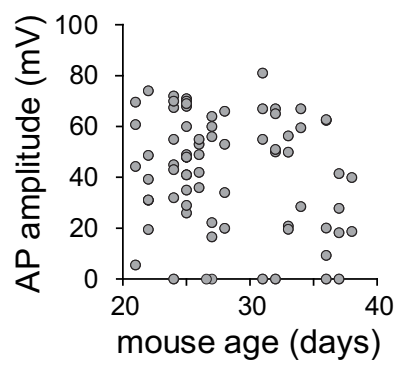

$\mathbf{F}$

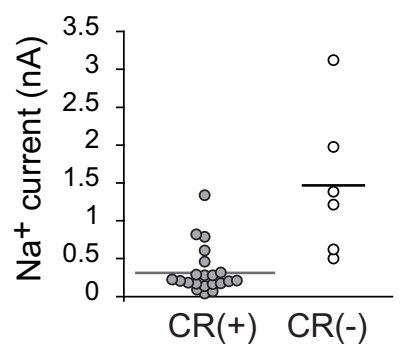

Figure 3. Intrinsic membrane properties of $\mathrm{CR}(+) / \mathrm{EGFP}(+) \mathrm{PG}$ cells. $\boldsymbol{A}$, Voltage responses of three representative $\mathrm{CR}(+) \mathrm{PG}$ cells to $500 \mathrm{~ms}$ long current steps. Cell 1 did not fire, Cell 2 fired a small non-overshooting action potential and Cell 3 fired a single overshooting action potential followed by a spikelet. Inset, Red traces are a zoom on the first suprathreshold response of Cells 2 and 3. $\boldsymbol{B}$, Distribution histogram of action potential amplitudes across all the EGFP(+) PG cells tested. $\boldsymbol{C}$, The amplitude of the action potential did not depend on the age of the mouse. $\boldsymbol{D}$, Depolarizing voltage steps $(5 \mathrm{mV} / 500 \mathrm{~ms})$ induced fast inward $\mathrm{Na}^{+}$currents and outward $\mathrm{K}^{+}$currents (inset, higher-magnification). The hyperpolarizing prepulse $\left(-40 \mathrm{mV}\right.$ from $\left.V_{\mathrm{h}}=-75 \mathrm{mV}\right)$ evoked an $/ \mathrm{h}$ current (arrow). $\boldsymbol{E}, \mathrm{Na}^{+}$currents were isolated in the presence of $\mathrm{K}^{+}$and $\mathrm{Ca}^{2+}$ channel blockers (Cs, TEA, 4-AP, and Cd). $\boldsymbol{F}$, Maximal Na ${ }^{+}$current amplitudes recorded in CR(+)/EGFP(+) PG cells compared with those recorded in $\mathrm{CR}(-) \mathrm{PG}$ cells in the same slices. Recordings were done as in $\boldsymbol{E}$.

specific period of maturation. BrdU was administered to $30-\mathrm{d}-$ old CR::EGFP mice $(n=20)$ to label cells generated at that age. Mice were then killed at different intervals (15-60 d) after the injection to evaluate the time window during which BrdUexpressing $\mathrm{CR}(+)$ PG cells express EGFP. This analysis revealed that the percentage of $\operatorname{BrdU}(+) / \operatorname{EGFP}(+)$ PG cells among $\mathrm{BrdU}(+) / \mathrm{CR}(+)$ PG cells $(\sim 50 \%)$ remained stable up to $60 \mathrm{~d}$ postinjection, thereby excluding a transient expression of EGFP in $\mathrm{CR}(+) \mathrm{PG}$ cells. Thus, EGFP expression is not transient and labels a fraction of $\mathrm{CR}(+) \mathrm{PG}$ cells that can be anywhere between 15- and, at least, 60-d-old (Fig. 2F). Together, these data indicate that EGFP stably labels a population of $\mathrm{CR}(+)$ PG cells that includes a representative population of neurons, from different spatial origin and at different stages of maturation.

\section{$\mathrm{CR}(+)$ PG cells fire at most one action potential at any stage of maturation}

Having established that EGFP expression faithfully reflects the spatiotemporal diversity of $\mathrm{CR}(+) \mathrm{PG}$ cells, we examined the functional properties of $\mathrm{EGFP}(+)$ PG cells using patch-clamp recording in acute olfactory bulb horizontal slices from CR:: EGFP mice. First, we examined the intrinsic membrane properties of $\operatorname{EGFP}(+)$ PG cells using whole-cell recordings. EGFP $(+)$ PG cells had an electrical membrane resistance of $2.0 \pm 0.12 \mathrm{G} \Omega$ $(n=74)$. This high membrane resistance, which is most likely underestimated because of the current leak through the pipette seal, suggests the expression of few ionic channels. In the currentclamp mode, depolarizing current injections from a holding potential maintained $\sim-70 \mathrm{mV}$ induced at most a single action potential, sometime followed by a spikelet (Fig. 3A). Further depolarizing the membrane did not elicit additional action potentials and, instead, passively depolarized the cell to positive potentials until the end of the step. This passive depolarization was seen in every cell tested and was therefore a robust functional marker of CR $(+)$ PG cells. Only $60 \%$ of the cells $(n=47 / 77)$ fired an overshooting action potential (with an amplitude $>40 \mathrm{mV}$; Fig. $3 B$ ). The other cells did not fire at all or fired a single rudimentary action potential (amplitude $<40 \mathrm{mV}, n=30$ ), much like immature newborn granule cells in the olfactory bulb (Carleton et al., 2003) or in the hippocampus (Overstreet et al., 2004; Espósito et al., 2005). Three examples of this diversity are shown in Figure $3 A$. EGFP $(+)$ PG cells firing a full size action potential had more complex voltage responses and significantly faster membrane time constant $(14.1 \pm 1.4 \mathrm{~ms}$ for $n=13$ cells with spike height $>65 \mathrm{mV}$ vs $26.6 \pm 1.8 \mathrm{~ms}$ for $n=13$ cells with spike height $<20 \mathrm{mV}, p<0.0001$ ), consistent with a maturation of the membrane properties. In the most mature cells, the action potential was sometime riding on the top of a calcium spike, and hyperpolarizing steps evoked a sag in membrane potential suggesting the activation of an $I_{\mathrm{h}}$ current. In rare cases, we re- 
A

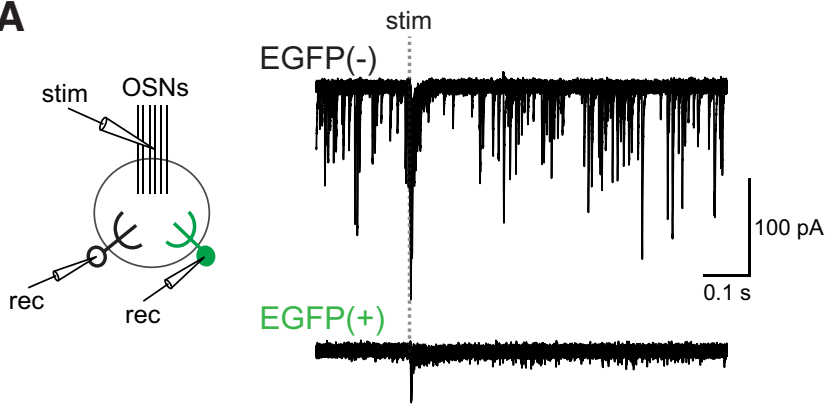

B
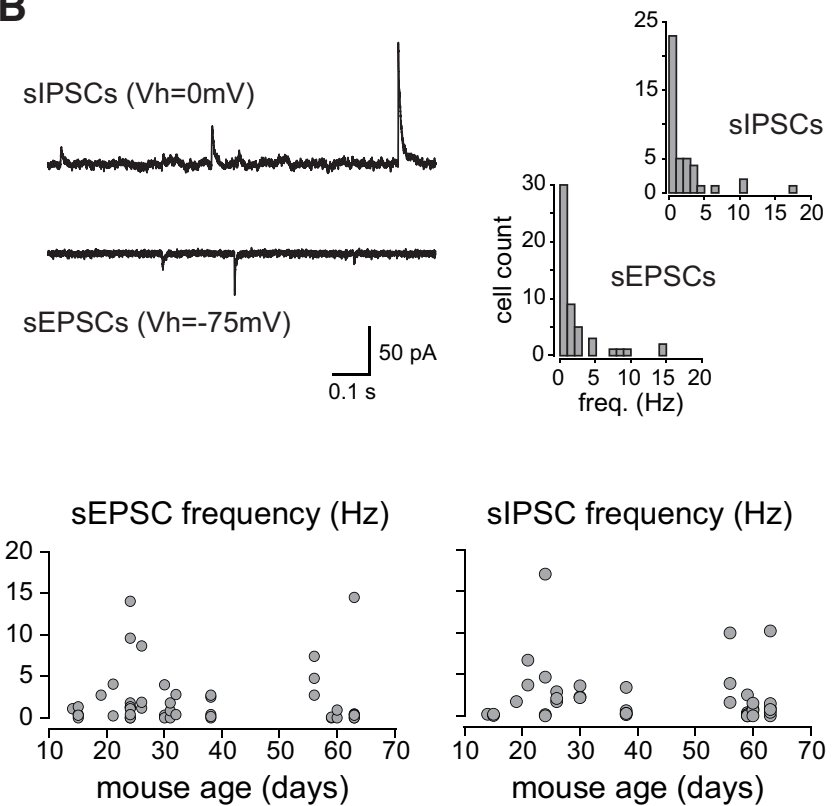

sIPSC frequency $(\mathrm{Hz})$

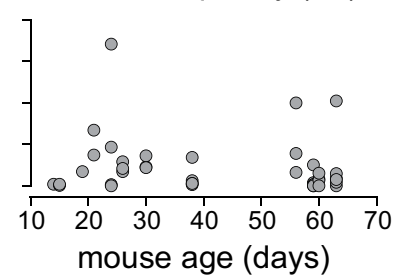

C

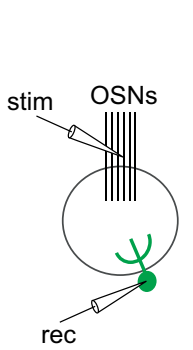

stim

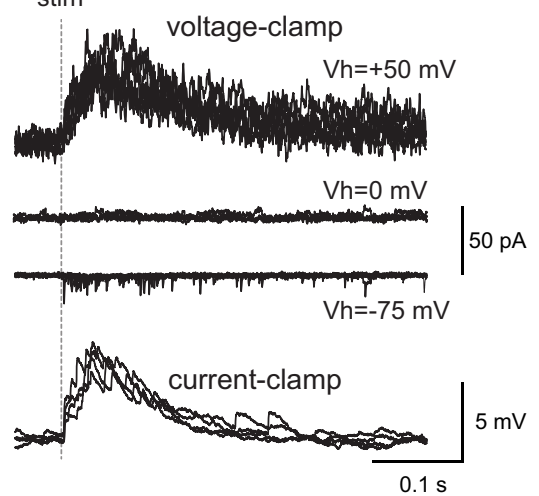

D

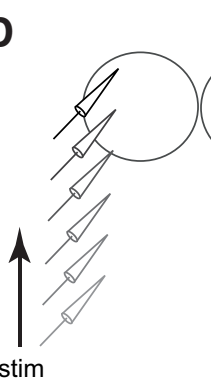

tim

$0.1 \mathrm{~s}$

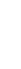

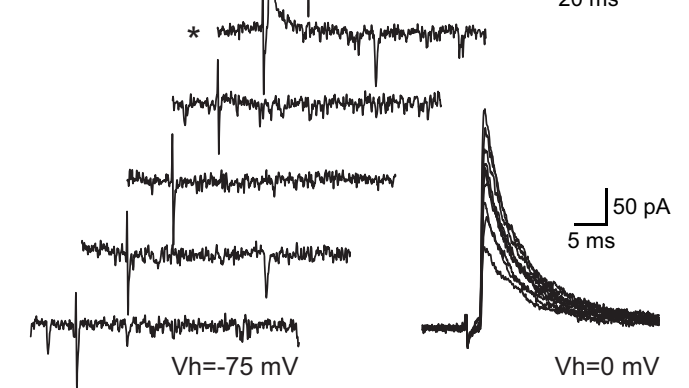

Figure 4. Synaptic inputs of $C R(+) / E G F P(+) P G$ cells. $A$, Paired recording between an $E G F P(+) / C R(+) P G$ cell and a nonlabeled $P G$ cell projecting into the same glomerulus. Fifteen traces are superimposed for each cell. The dashed line indicates OSN stimulation. $\boldsymbol{B}$, Spontaneous IPSCS (sIPSCs recorded at $V_{\mathrm{h}}=0 \mathrm{mV}$; top trace) and EPSCs (sEPSCs recorded at $V_{\mathrm{h}}=-75 \mathrm{mV}$; bottom trace) in a representative EGFP $(+) / C R(+) P G$ cell. Right, Distribution histograms (bin of $1 \mathrm{~Hz}$ ) of synaptic input frequencies showing the predominance of cells receiving few inputs. Bottom, Summary graphs of sEPSCs and sIPSCs frequencies in cells from mice at different developmental ages. Each dot represents a cell. $C$, OSN-evoked synaptic responses of an EGFP(+)/CR(+) PG cell recorded in the voltage-clamp mode at a positive holding potential (top traces), at the equilibrium potential for excitation (middle traces) or at a negative potential (middle traces), and in the current-clamp mode (bottom traces). Several traces are superimposed each time. Stimulation, $150 \mu A$. D, Distant stimulations in the glomerular layer or in the EPL failed to evoke any EPSC in EGFP(+)/CR(+) PG cells clamped at $V_{\mathrm{h}}=-75 \mathrm{mV}$. In contrast, an outward IPSC was sometime evoked (traces marked with an asterisk). Traces are representative responses selected over $>80$ trials (stimulation intensity $500 \mu \mathrm{A}$ ). Inset, Several consecutive IPS(s evoked by a distant stimulation and recorded at $V_{\mathrm{h}}=0 \mathrm{mV}$.

corded cells that spontaneously and regularly fired a single action potential at $\sim 0.5-1 \mathrm{~Hz}$ (data not shown). This cell to cell variability, that can be illustrated using the size of the spike as an indicator of cell maturation, was often seen within the same slice from animals at different developmental ages (P15-P38; Fig. 3C). Thus, consistent with their ongoing production, $\mathrm{CR}(+) \mathrm{PG}$ cells constitute a population of neurons with variable membrane properties that likely reflect different stages of maturation.

Next, we examined the voltage-activated conductances underlying the membrane potential responses. Consistent with a recently published study (Fogli Iseppe et al., 2016), classical voltage-clamp protocols activated few conductances and, remarkably, no delayed $\mathrm{K}^{+}$currents. Although inward $I_{\mathrm{h}}$ currents were often induced by a $40 \mathrm{mV}$ hyperpolarizing pre-pulse, depolarizing steps only evoked fast inward $\mathrm{Na}^{+}$currents followed by large and rapidly inactivating outward $\mathrm{K}^{+}$currents (Fig. 3D). $\mathrm{Ca}^{2+}$ inward currents were not seen under these recording conditions suggesting that they may be too small to be detected (Fogli Iseppe et al., 2016). Outward $\mathrm{K}^{+}$currents $\left(1 \pm 0.1 \mathrm{nA}\right.$ at $V_{\mathrm{h}}=$
$-10 \mathrm{mV}$ ) were fast (deactivation time constant: $12.4 \pm 1.0 \mathrm{~ms}$, $n=19)$ in every cell tested, and strongly reduced by a $20 \mathrm{mV}$ depolarizing prepulse ( $88 \pm 2 \%$ decrease, $n=9$, data not shown), consistent with A-type $\mathrm{K}^{+}$currents. $\mathrm{Na}^{+}$currents were often small or totally absent in some cells ( $n=21$ cells; Fig. $3 E, F)$ and only a fraction of the cells expressed $\mathrm{Na}^{+}$currents comparable in size to those seen in other nonlabeled PG cell subtypes. Together, these data indicate that $\operatorname{EGFP}(+)$ PG cells, regardless of their degree of maturation, express a surprisingly small variety of voltage-activated conductances.

\section{$\mathrm{CR}(+)$ PG cells are weakly connected to the local} glomerular network

We have already shown that $\operatorname{EGFP}(+)$ PG cells receive less spontaneous excitatory synaptic inputs (sEPSC) from mitral and tufted cells than other type 2 PG cells and thus respond to a stimulation of the olfactory nerve with a smaller composite EPSC (Najac et al., 2015). This is here illustrated with a paired recording of two PG cells, one $\operatorname{EGFP}(+)$ and one $\operatorname{EGFP}(-)$, projecting into 

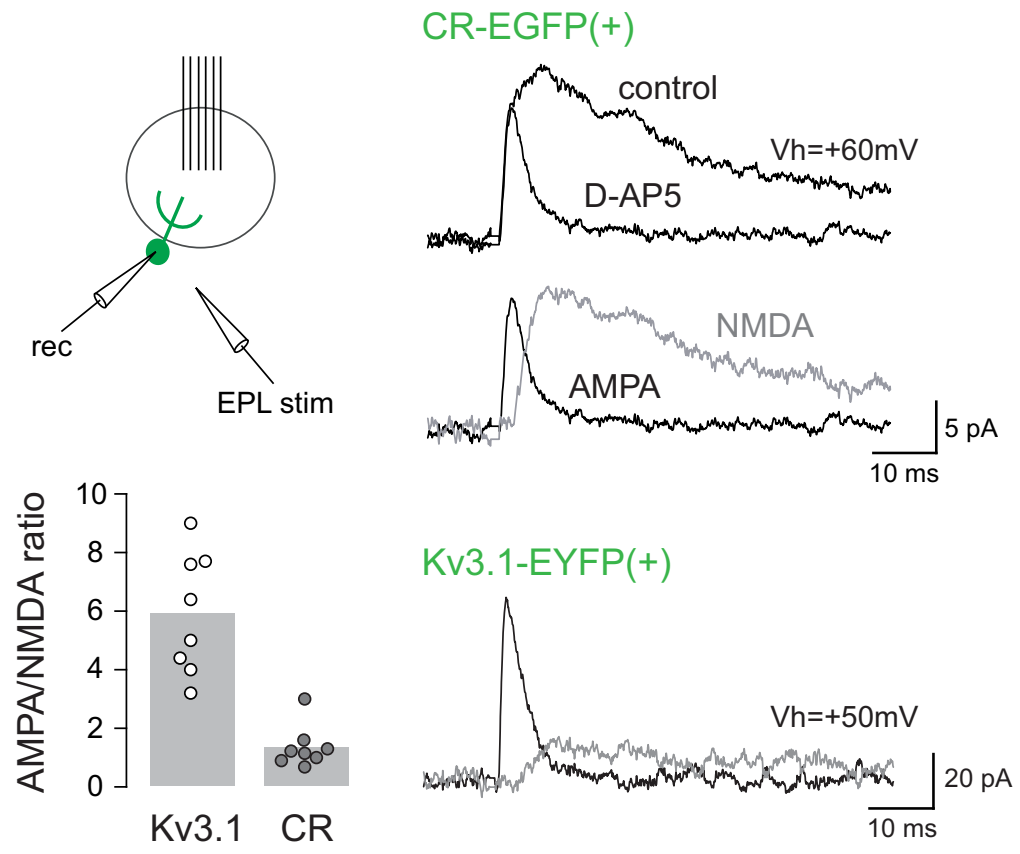

Figure 5. Excitatory synapses are enriched with NMDA receptors in $\mathrm{CR}(+) / \mathrm{EGFP}(+) \mathrm{PG}$ cells. Comparison of AMPA/NMDA ratios at excitatory synapses in CR-EGFP(+) PG cells (top traces) and in Kv3.1-EYFP(+) PG cells (bottom traces). EPSCs were elicited by an electrical stimulation in the EPL and recorded at a positive holding potential in control conditions and in the presence of D-AP5 $(50 \mu \mathrm{m})$. The NMDA component (gray trace) was obtained by subtracting the D-AP5 trace from the control trace. Summary bars show the average AMPA/NMDA ratio in $\mathrm{CR}(+) / \mathrm{EGFP}(+) \mathrm{PG}$ cells and in Kv3.1-EYFP( + ) PG cells. Each dot represents a cell.

the same glomerulus (Fig. 4A). To complement our previous analysis, we recorded sEPSC from animals at different ages $(n=$ 52 cells) and also examined their spontaneous inhibitory inputs (sIPSC; $n=42$ cells). The majority of the cells tested received a low frequency of sEPSCs ( $90 \%$ received $<5$ sEPSC/s and $75 \%<2$ sEPSC/s; Fig. 4B). This frequency is much lower than in other type 2 PG cells. For instance, PG cells labeled in the Kv3.1::EYFP reporter mouse on average receive $17 \mathrm{sEPSC} / \mathrm{s}$ (Najac et al., 2015). EGFP $(+)$ cells also received few spontaneous IPSC $(90 \%$ $<5$ sIPSC/s and nearly $70 \%<2$ sIPSC/s). There was no obvious relationship between the frequencies of sEPSC and sIPSC in cells in which these two synaptic inputs were recorded (data not shown). There was also no obvious relationship between the age of the animal and the synaptic input frequencies in $\operatorname{EGFP}(+) \mathrm{PG}$ cells (Fig. 4B). Remarkably, cells receiving no spontaneous synaptic input were observed at all ages.

Stimulation of the OSN evoked few fast asynchronized EPSCs in $\operatorname{EGFP}(+)$ cells voltage-clamped at negative potentials, consistent with the small number of connections with mitral and tufted cells (Fig. 4C). This stimulus induced no IPSC when cells were clamped around the reversal potential for EPSCs $\left(V_{\mathrm{h}}=0 \mathrm{mV}\right.$, $n=10)$ indicating that $\operatorname{EGFP}(+)$ cells are also not connected to local interneurons (Fig. 4C). Together, these responses indicate that $\mathrm{CR}(+) \mathrm{PG}$ cells are weakly connected to the glomerular network. However, CR $(+)$ PG cells could be connected to other brain areas through top-down fibers. To test this idea, we stimulated strongly (0.5-1 mA, $n=9$ cells in P57- to P64-d-old mice) at $>200 \mu \mathrm{m}$ from the recorded cell at different locations within the glomerular layer or within the EPL where excitatory axons from the olfactory cortex (Boyd et al., 2012) and inhibitory fibers from the basal forebrain (Gracia-Llanes et al., 2010) can be found. Our recent data demonstrate that these distant extraglomerular stimulations activate basal forebrain GABAergic inputs onto diverse subtypes of PG cells, including $\mathrm{CR}(+)$ PG cells (Sanz Diez et al., 2017). In line with these data, IPSCs were eventually elicited whereas EPSCs were never evoked (Fig. 4D). Thus, CR(+) PG cells receive centrifugal inhibitory inputs but are unlikely innervated by top-down glutamatergic afferents.

\section{Excitatory synapses are immature on $\mathrm{CR}(+)$ PG cells}

Small OSN-evoked EPSCs (average amplitude $12 \pm 3 \mathrm{pA}$ at $V_{\mathrm{h}}=-75 \mathrm{mV}, n=5$ ) converted into slow summating EPSPs and produced a significant depolarization in the current-clamp mode $(6 \pm 1 \mathrm{mV}$, $n=5$; Fig. 4C). Interestingly, the slow time course of the OSN-evoked EPSP was similar as the time course of the OSNevoked EPSC recorded in voltage-clamp at a positive holding potential, suggesting a strong contribution of NMDA receptors at mitral/tufted to $\mathrm{CR}(+) \mathrm{PG}$ cell synapses. To further test this hypothesis, we determined the relative contribution of AMPA and NMDA receptors in individual EPSCs. Excitatory mitral or tufted cell inputs were evoked by an electrical stimulation in the EPL. Evoked EPSCs mediated by both AMPA and NMDA receptors were recorded at a positive holding potential $\left(V_{\mathrm{h}}=+50 / 60 \mathrm{mV}\right)$, first in control condition and then in the presence of the NMDA receptor antagonist D-AP5 $(50 \mu \mathrm{M})$ to isolate the AMPA component. Then, we quantified the AMPA/NMDA ratio of the individual EPSC (Fig. 5). Under these conditions, the AMPA/NMDA ratio at mitral/tufted cells to $\mathrm{CR}(+) \mathrm{PG}$ cell synapses was $1.4 \pm$ $0.2(n=8 \mathrm{EGFP}(+) \mathrm{PG}$ cells $)$. All the cells included in this analysis, i.e., those in which it was possible to evoke a large enough individual EPSC, fired an overshooting action potential (amplitude range $42-67 \mathrm{mV}$ ) suggesting that they are among the most "mature" CR $(+)$ PG cells. Yet, their AMPA/NMDA ratio at excitatory synapses was several folds lower than in PG cells labeled in the Kv3.1::EYFP reporter mouse [AMPA/NMDA ratio: $5.9 \pm$ $0.7, n=8 \mathrm{EYFP}(+)$ PG cells, $t_{(8)}=5.9, p<0.0001$; Fig. 5]. This confirms the high density of NMDA receptors at excitatory synapses on $\mathrm{CR}(+)$ PG cells, a feature of immature synapses.

\section{Synaptic integration of CR(+) PG cells does not progress over time}

The diversity of membrane properties observed in our random sampling of EGFP $(+)$ PG cells is consistent with a developmental maturation of the intrinsic membrane properties across cells generated at different time. How synaptic integration progress in time is less clear. To clarify this question, we examined the properties of age-matched EGFP $(+)$ PG cells colabeled, using targeted EPO of the septal SVZ, with tdTomato (Fig. 6A). Tom $(+) /$ $\mathrm{EGFP}(+) \mathrm{PG}$ cells were recorded at different intervals after EPO ( $n=50$ cells, $15-63 \mathrm{~d}$ after EPO). As expected, these cells had similar properties as those described before, i.e., they fired at most a single action potential and received little spontaneous synaptic inputs. However, most of the cells tested fired an overshooting action potential ( $n=22 / 25$ at $\geq 20 \mathrm{~d}$ after EPO; Fig. $6 B$ ) suggesting that cells that did not fire or fired a rudimentary action 
A

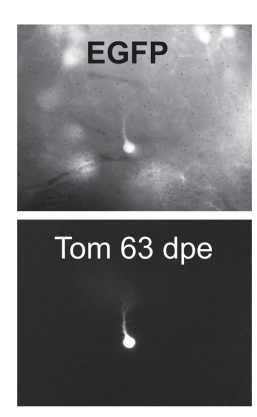

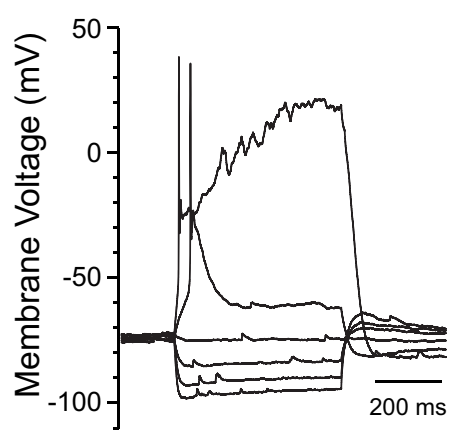

B

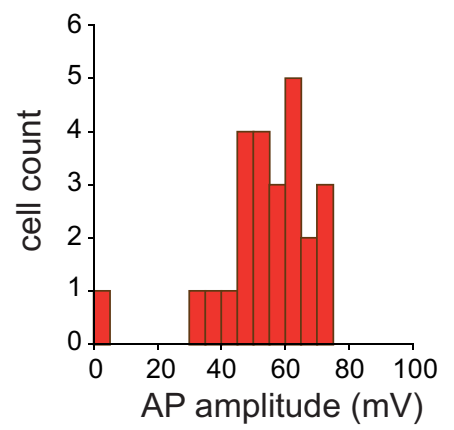

C
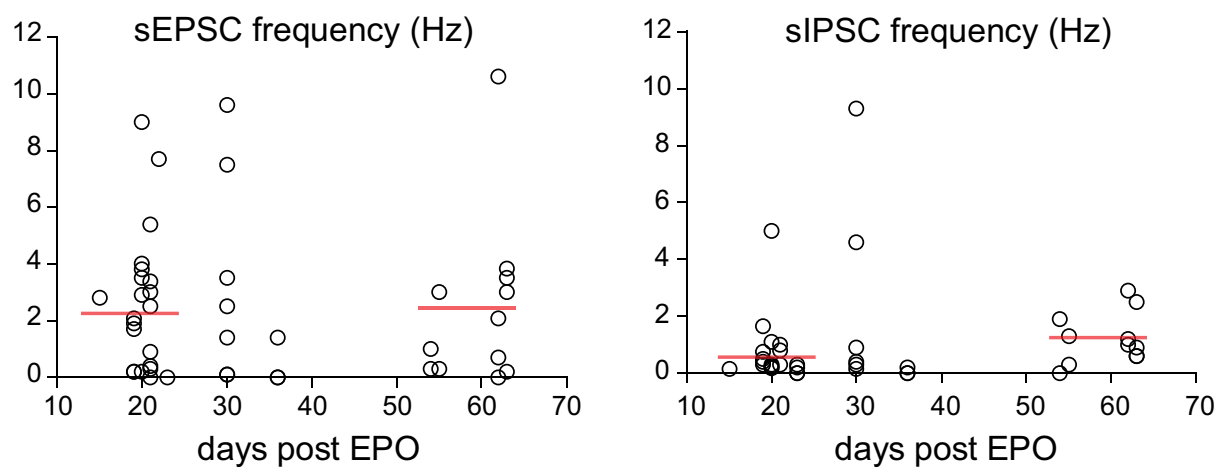

Figure 6. Synaptic integration of $C R(+) / E G F P(+) P G$ cells does not change over time. $\boldsymbol{A}$, Current-voltage relationship of an $E G F P(+) P G$ cell (top) colabeled with Tom (bottom), 63 d after EP0 of a Tom-expressing plasmid in a CR::EGFP transgenic mouse. $\boldsymbol{B}$, Distribution of action potential amplitudes in all the EGFP $(+) /$ Tom $(+)$ cells recorded $19-63 \mathrm{~d}$ post-EP0. $\boldsymbol{C}$, Excitatory (left) and inhibitory (right) input frequencies in $\operatorname{EGPP}(+) / \mathrm{Tom}(+) \mathrm{PG}$ cells recorded at different intervals after EPO. Each dot represents a cell. Horizontal bars show average frequencies for cells recorded at $15-23$ d or $54-63$ d post-EPO.

potential in our random sampling of $\operatorname{EGFP}(+)$ PG cells were $<20$-d-old. In contrast, the frequency of the spontaneous synaptic inputs was not correlated with the age of the cell (Fig. 6C). Similar to randomly chosen $\operatorname{EGFP}(+)$ PG cells, Tom $(+) /$ EGFP $(+)$ PG cells received between 0 and 10 EPSCs per second (mean $2.3 \pm 2.7, n=47$ ) and, for the majority of them, $<3$ IPSCs/s (mean $1.0 \pm 1.7, n=41$ ) whether they were young (15-23 d post-EPO) or older (54-63 d post-EPO). Thus, the mean frequency of sEPSC was not different in young cells (2.2 \pm $0.5 \mathrm{EPSC} / \mathrm{s}, n=25)$ and in old cells $(2.4 \pm 0.8 \mathrm{EPSC} / \mathrm{s}, n=12, p=$ $0.88)$. The mean sIPSC frequency was also not different in young cells $(0.7 \pm 0.2 \mathrm{IPSC} / \mathrm{s}, n=21)$ and in old cells $(1.2 \pm 0.3 \mathrm{IPSC} / \mathrm{s}$, $n=11, p=0.17)$. Importantly, cells without any detectable synaptic inputs were recorded at all ages. Thus, synaptic integration of $\mathrm{CR}(+) \mathrm{PG}$ cells does not progress over time.

\section{$\mathrm{CR}(+)$ PG cells are less recruited than other PG cells}

Low innervation counteracts high intrinsic membrane excitability and prevents the firing of newly generated immature neurons (Dieni et al., 2016). In the other hand, temporal summation of small, input-specific, NMDA receptor-mediated EPSPs converts into reliable spiking in immature neurons (L. Li et al., 2017). Thus, sparse activation of immature neurons may play important and specific functions in circuit computation. We examined the afferent-driven recruitment of $\mathrm{CR}(+) \mathrm{PG}$ cells using paired loose cell-attached recording. We compared the OSN-evoked firing activity of EGFP $(+)$ PG cells with those of other PG cell subtypes embedded in the same network. Stimulation intensities were first adjusted to reliably elicit the discharge of a randomly chosen EGFP(-) PG cell. Then, we simultaneously recorded from an $\operatorname{EGFP}(+)$ cell projecting into the same glomerulus $(n=18$ pairs in slices from P31-P39 old mice). As illustrated in Figure $7 A$, spontaneous and evoked action potential capacitive currents were classically biphasic and large in $\operatorname{EGFP}(-)$ PG cells (average amplitude $121 \pm 28 \mathrm{pA}$, range $18-532 \mathrm{pA}$; Fig. $7 \mathrm{C}$ ). The number of spikes evoked by the stimulation of the OSNs (from 2 to $>16$, average $5.8 \pm 4$ ), as well as the duration of the burst varied across cells, consistent with the diverse functional profiles of PG cells (Fig. 7 A, B; Najac et al., 2015). In sharp contrast, OSN stimulations produced no response at all ( $n=8$ cells) or a single, occasionally two, small monophasic capacitive currents $(15 \pm 2 \mathrm{pA}$, $n=10$ cells) in $\operatorname{EGFP}(+)$ PG cells (Fig. $7 A-C)$. Increasing the intensity of stimulation did not change the responses indicating that $\operatorname{EGFP}(+) \mathrm{PG}$ cells do not have a higher activation threshold. Moreover, spontaneous spikes were rarely seen in $\operatorname{EGFP}(+)$ cells (few events seen in only $3 / 18$ cells) whereas they were frequent and seen in the majority of $\operatorname{EGFP}(-)$ cells $(11 / 18)$. Thus, $\mathrm{CR}(+)$ PG cells are remarkably silent compared with other PG cell subtypes and, in sharp contrast with other type 2 PG cells (Najac et al., 2015), are poorly recruited by afferent inputs.

We also investigated the activity of $\mathrm{CR}(+) \mathrm{PG}$ cells in vivo using the expression of the immediate early gene c-Fos as a marker of cellular activation (Fig. 7D). We compared the relative activation of various PG cell subtypes under basal conditions in mice housed in their regular cage. In these animals, occasional glomeruli were heavily labeled by a c-Fos immunostaining $(n=$ $1104 \mathrm{c}-\mathrm{Fos}+$ cells in 3 mice). In these glomeruli, the majority of $\mathrm{CB}(+) \mathrm{PG}$ interneurons were positive for $\mathrm{c}-\mathrm{Fos}(72.3 \pm 2 \%)$, in line with their pronounced activity in vitro and in vivo in anesthetized animals (Najac et al., 2015). In comparison, a smaller percentage of $\mathrm{TH}(+)$ PG interneurons were positive for this immediate early gene $(28.1 \pm 7 \%)$, while only rare $\mathrm{CR}(+)$ c-Fos $(+)$ PG cells were observed $(11.5 \pm 1 \%)$ consistent with their low network-driven activity in slices. Thus, these data suggest that the 
A

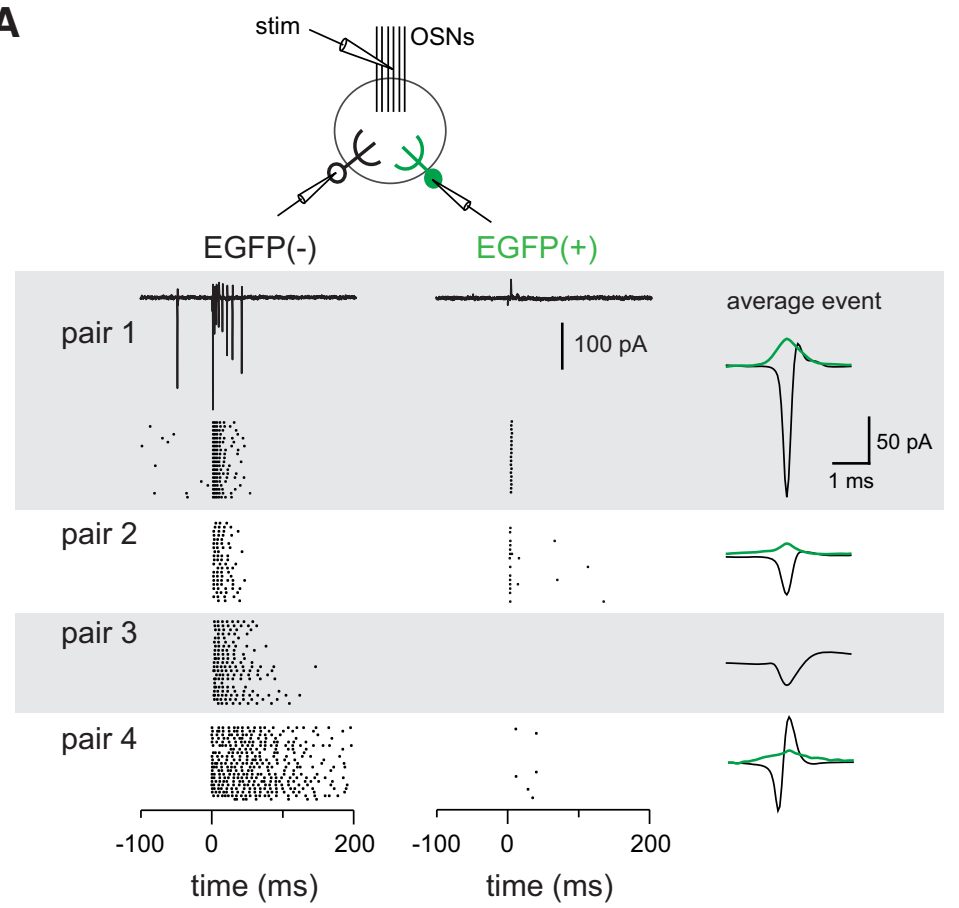

D

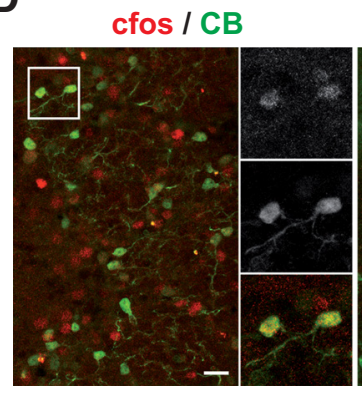

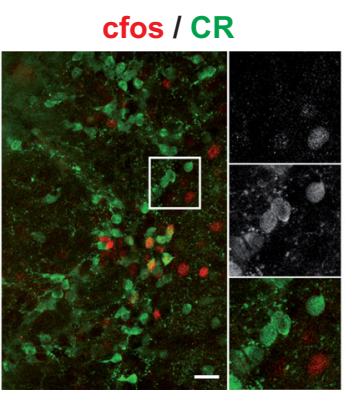

B

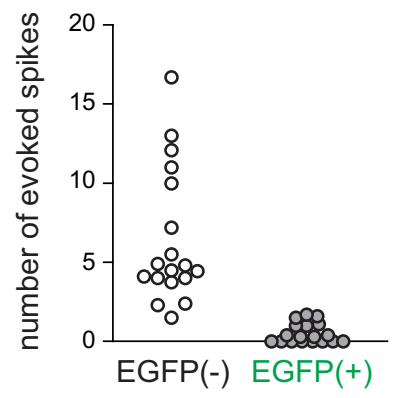

C
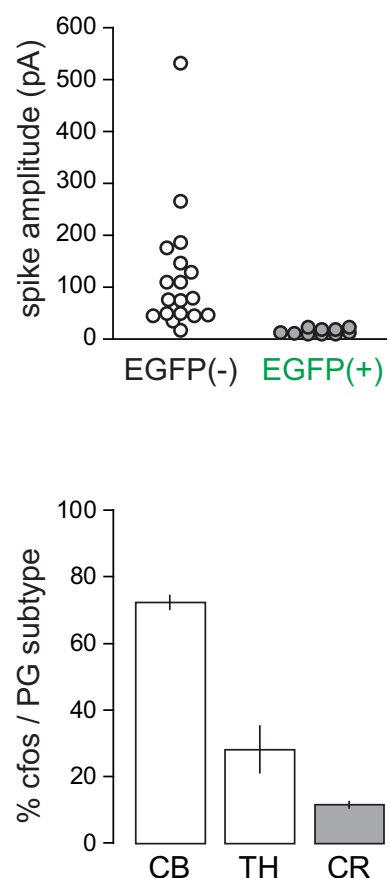

Figure 7. $\mathrm{CR}(+) \mathrm{PG}$ cells are poorly recruited in vitro and in vivo. $A, 0$ SN-driven spiking of $\mathrm{EFP}(+) / \mathrm{CR}(+) \mathrm{PG}$ cells in olfactory bulb slices. Two $\mathrm{PG}$ cells projecting into the same glomerulus, one $\operatorname{EGFP}(+)$ and one EGFP $(-)$, were recorded in the loose-cell attached configuration. Their firing was elicited by an electrical stimulation of the 0SNs. Raster plots from four pairs are shown with 20 consecutive sweeps for each pair. The EGFP( - ) cell is on the left, the EGFP( + ) on the right. A typical response is shown for Pair 1. OSNs were stimulated at $t=0$, at an intensity of $30-200 \mu A$ (stimulation artifact has been blanked). The average evoked capacitive action current is shown on the right for each pair [green trace: EGFP(+) cell; black trace: EGFP(-) cell]. B, C, Summary plots of the results ( $n=18$ pairs). $\boldsymbol{B}$, Average number of spikes evoked within the $200 \mathrm{~ms}$ following the stimulation. $\boldsymbol{C}$, Amplitudes of the average capacitive currents evoked by the stimulation. $\boldsymbol{D}$, $c-$ Fos expression in $\mathrm{PG}$ interneuron subtypes ( $(B+,(\mathrm{R}+, \mathrm{TH}+$ ) in activated glomeruli in vivo. Insert, Higher-magnifications of select region (boxes on overviews). The graph shows the proportion of each PG interneuron subtypes expressing c-Fos. Scale bars, $25 \mu \mathrm{m}$.

physiological properties of $\mathrm{CR}(+)$ PG cells limit their contribution in local network activity.

\section{Do $\mathrm{CR}(+)$ PG cells release GABA?}

The impact of $\mathrm{CR}(+) \mathrm{PG}$ cells on the glomerular network does not only depend on establishing the appropriate afferent connections that induce its firing but also on its capability to release GABA at output synapses. Ultrastructural evidence supporting the existence of functional output synapses from $\mathrm{CR}(+)$ PG cells are sparse in the literature compared with those concerning $\mathrm{CB}(+)$ and $\mathrm{TH}(+)$ cells. Nonetheless, it is generally believed that they establish GABAergic dendrodendritic synapses with mitral and tufted cells (Panzanelli et al., 2007). We thus made pairedrecordings between $\operatorname{EGFP}(+) / \mathrm{CR}(+)$ PG cells and mitral $(n=9$ pairs), tufted ( $n=7$ pairs) or external tufted cells ( $n=4$ pairs). The principal neuron was first loaded with an intracellular solution containing a fluorescent dye to visualize its dendritic tree and its projection glomerulus. Next, we patched an $\mathrm{EGFP}(+) / \mathrm{CR}(+)$ PG cell surrounding this glomerulus. Both neurons were filed with a fluorescent dye to insure during recording their overlapping dendritic trees. A series of 10 spikes was then induced in the PG cell with short depolarizing steps (2 ms every $50 \mathrm{~ms}$ ) while the mitral/tufted cell was voltage-clamped at a potential closed to the equilibrium potential for excitation $\left(V_{\mathrm{h}}=0 /+10 \mathrm{mV}\right)$. However, under these conditions, we found no evidence for spikeinduced GABA release in any of the pairs tested (data not shown). Self-inhibition is another read-out for GABA release in many PG cells (Smith and Jahr, 2002; Murphy et al., 2005; Maher and Westbrook, 2008). Consistent with this, a short depolarizing pulse triggered a GABA-mediated tail current in all the Kv3.1EYFP $(+)$ PG cells tested (average amplitude $358 \pm 42 \mathrm{pA}, n=9$; Fig. 8). In contrast, no auto-inhibition was seen in any of the EGFP $(+) / C R(+)$ PG cells tested under similar conditions $(n=$ 10). These observations, together with their immature electro- 
physiological properties and their low synaptic connectivity, question the ability of CR $(+)$ PG cells to establish functional output synapses and participate in local network activity.

\section{Discussion}

Our study shows that CR $(+)$ PG cells, independent of their spatial origin and age, receive little synaptic inputs and do not fire or fire at most a single and often small action potential in response to stimuli that strongly activate other PG cells. Altogether, the synaptic and intrinsic properties of CR $(+)$ PG cells resemble those of immature neurons not yet integrated in the preexisting network. Surprisingly, however, our birth dating experiments indicate that $\mathrm{CR}(+) \mathrm{PG}$ cells remain in this immature stage for weeks, if not months, as if they would never fully mature. Thus, $\mathrm{CR}(+)$ PG cells constitute a particularly large pool of neurons with nonconventional properties and still unknown functions.

\section{Calretinin defines a homogeneous population of PG interneurons with complex spatio-temporal origins}

Our long term fate mapping of neural stem cells located in defined SVZ walls confirms the dual origin of CR(+) PG interneurons from the dorsal and the septal SVZ throughout postnatal life (Fernández et al., 2011) and extent it to adulthood. The persistent dorsal origin of $\mathrm{CR}(+)$ PG interneurons observed at $\mathrm{P} 90$ is consistent with a previous fate mapping study reporting that a fraction of these cells derives from the pallium (Emx1 lineage), which gives rise to the dorsal part of the postnatal SVZ (Kohwi et al., 2007). This previous report also showed that a fraction of $\mathrm{CR}(+) \mathrm{PG}$ interneurons derives from the Dlx5/6 lineage, a transcription factor that is strongly active in the embryonic lateral ganglionic eminence and in the septum which give rise to the lateral and septal parts of the postnatal SVZ, respectively. Our observations indicate that $\mathrm{CR}(+) \mathrm{PG}$ interneurons from the Dlx5/6 lineage originate from the septal most regions of the postnatal SVZ because they were consistently absent following lateral SVZ EPO at both postnatal and adult stages. The rapid decrease of germinal activity observed in the septal wall during the first $15 \mathrm{~d}$ of postnatal life suggests, however, that the proportion of $\mathrm{CR}(+)$ interneurons originating from the dorsal SVZ gradually increases over time, consistent with the gradual increase in the proportion of $\mathrm{CR}(+)$ interneurons originating from the Emxl lineage with age (Kohwi et al., 2007).

We demonstrate that this complex spatial and temporal origin does not translate into morphological and electrophysiological differences. Using the CR::EGFP reporter mouse line, we found that $\mathrm{CR}(+)$ PG cells originating from distinct stem cells and generated at different developmental ages have rather uniform properties. The variability of some of these properties likely reflects different stages of maturation rather than different origins. However, EGFP labels only half of the CR-expressing PG cells in adult mice, leaving open the possibility that unlabeled $\mathrm{CR}(+) \mathrm{PG}$ cells form a different subpopulation of neurons with more mature properties and a possibly different impact on the glomerular network. Several observations, however, suggest that the coexistence of two distinct $\mathrm{CR}(+)$ PG cell populations is unlikely. First, we demonstrate that EGFP is expressed for at least 2 months in $\mathrm{CR}(+) \mathrm{PG}$ cells, unlike in other transgenic models in which newborn neurons transiently express a reporter during a defined period of their maturation (Overstreet et al., 2004; Spampanato et al., 2012). Second, we show that the morphology of EGFP $(+)$ and $\mathrm{EGFP}(-) \mathrm{CR}(+)$ PG cells is largely similar. Third, PG cells that do not fire in response to OSN stimulation represent $\sim 40 \%$ of the PG cells in our previous blind recordings, consistent with the abundance of $\mathrm{CR}(+) \mathrm{PG}$ cells relative to other subtypes (Najac et al., 2015). Fourth, a recent study reported similar intrinsic membrane properties in $\mathrm{CR}(+) \mathrm{PG}$ cells expressing EGFP in another transgenic strain (Fogli Iseppe et al., 2016). Thus, despite their incomplete labeling in the transgenic mouse used in our study, $\mathrm{CR}(+)$ PG cells likely constitute a single population of neurons.

\section{$\mathrm{CR}(+)$ PG cells show properties of immature neurons that persist over time}

Several subtypes of neurons continue to be produced after birth. In the olfactory bulb, a majority of inhibitory granule cells are produced in parallel to a smaller population of various PG interneurons. Neurogenesis also persists in the hippocampus from stem cells located in the subgranular zone of the dentate gyrus. The maturation and integration of these newborn neurons in the preexisting network has been examined in great details in both 
structures and, despite small timing differences and specific synaptic connections, follows essentially the same sequence of morphological and functional maturation (for review, see Lepousez et al., 2015; Toni and Schinder, 2015). Interestingly, the properties of $\mathrm{CR}(+) \mathrm{PG}$ cells described in this paper are reminiscent of those of immature newborn neurons not yet fully integrated in the preexisting olfactory bulb or hippocampal network, i.e., 2-4 weeks after their birth (Carleton et al., 2003; Espósito et al., 2005). Like them, they have a large electrical input resistance and express a low density of voltage-activated channels. In addition, they fire at most a single action potential and many cells are not capable of firing a full size action potential, a property observed in newborn neurons up to 3 weeks after their birth. They also receive little synaptic inputs compared with resident interneurons. Finally, their excitatory synapses are enriched with NMDA receptors, a characteristic of immature and plastic excitatory synapses during postnatal development or during maturation in adult-generated newborn neurons (Ge et al., 2007; Grubb et al., 2008; Katagiri et al., 2011). However, these immature properties persist for extended periods of time in $\mathrm{CR}(+) \mathrm{PG}$ interneurons, greatly contrasting with the rapid activity-dependent maturation and integration (i.e., 4-6 weeks) of other populations of newborn bulbar or hippocampal interneurons (Belluzzi et al., 2003; Carleton et al., 2003; Espósito et al., 2005; Livneh et al., 2014).

\section{How do $\mathrm{CR}(+)$ PG cells participate to circuit function?}

Type 2 PG cells are activated by mitral and tufted cells and in turn collectively produce a strong feedback inhibition of these principal neurons (Najac et al., 2011, 2015; Shao et al., 2012, 2013; Geramita and Urban, 2017). Thus, OSN stimulation produces a barrage of unsynchronized summating IPSCs in mitral and tufted cells. The time course of this inhibition matches well with the burst of action potentials fired in non-CR type 2 PG cells (Najac et al., 2015). Current models suggest that this intraglomerular inhibition serves as a gatekeeper that shunt weak OSN inputs (Gire and Schoppa, 2009) and differently modulates mitral and tufted cells, thereby separating their firing phase along the respiration cycle (Fukunaga et al., 2012, 2014) and generating distinct modes of intensity coding in these two output channels (Geramita and Urban, 2017). Our data confirm that CR(+) PG cells are type 2 PG cells that receive few excitatory synaptic inputs from mitral/tufted cells. However, their stereotyped firing pattern and their uncertain GABA output suggest that their contribution to OSN-driven feedback inhibition of principal neurons is, at most, limited.

The small proportion of $\mathrm{CR}(+) \mathrm{PG}$ interneurons that receive a significant amount of excitatory synaptic inputs, and which likely represents their most advanced stage of maturation, cannot fire more than once in response to the temporally complex and prolonged depolarization induced by mitral and tufted cells (Fogli Iseppe et al., 2016). Yet, activation of these most "mature" $\mathrm{CR}(+) \mathrm{PG}$ cells produces temporally precise spikes. Collectively, their output could mediate a temporally precise IPSC with a significant impact on action potentials timing in postsynaptic neurons. However, these postsynaptic targets are unknown and a phasic OSN-driven inhibition that cannot adapt to the circuit's afferent activity has, to our best knowledge, not yet been observed in any of the neuronal populations that constitute the glomerular network.

$\mathrm{CR}(+)$ PG cells could also contribute, without spiking, to microcircuit computation through intraglomerular calciumdependent dendrodendritic interactions. However, their capacity to release GABA at output synapses has yet to be demonstrated.
Although our data do not exclude this possibility, we found no functional evidence supporting it. Moreover, previous works indicate that $\mathrm{CR}(+) \mathrm{PG}$ cells, quote, appear to establish fewer synapses than $\mathrm{CB}(+)$ and $\mathrm{TH}(+)$ cells (Panzanelli et al., 2007). A surprisingly large fraction of $\mathrm{CR}(+) \mathrm{PG}$ cells is also immunonegative for GAD/GABA (Kosaka and Kosaka, 2007) or VGAT, the vesicular transporter for GABA (Sawada et al., 2011), whereas $100 \%$ of $\mathrm{CB}(+)$ and $\mathrm{TH}(+)$ subtypes express these markers.

Altogether, our results reveal the atypical and intriguing properties of $\mathrm{CR}(+) \mathrm{PG}$ interneurons. Although our data do not entirely exclude the possibility that some $\mathrm{CR}(+) \mathrm{PG}$ cells are activated by extraglomerular pathways and inhibit specific, but still unknown, targets within the glomerular network, the function of this abundant and continuously produced neuronal population remains elusive. It is tempting to speculate that immature $\mathrm{CR}(+)$ cells constitutes a reserve pool of latent and not fully differentiated interneurons that could supply the glomerular network on demand, based on specific sensory experience. Such recruitment, that may take the form of a functional maturation or a fate conversion in other PG cell subtypes, would provide an unsuspected extra level of plasticity to the glomerular network and would compensate the lower postnatal neurogenesis of PG cells compared with granule cells.

\section{References}

Batista-Brito R, Close J, Machold R, Fishell G (2008) The distinct temporal origins of olfactory bulb interneuron subtypes. J Neurosci 28:3966-3975. CrossRef Medline

Belluzzi O, Benedusi M, Ackman J, LoTurco JJ (2003) Electrophysiological differentiation of new neurons in the olfactory bulb. J Neurosci 23:1041110418. CrossRef Medline

Boutin C, Diestel S, Desoeuvre A, Tiveron MC, Cremer H (2008) Efficient in vivo electroporation of the postnatal rodent forebrain. PLoS One 3:e1883. CrossRef Medline

Boyd AM, Sturgill JF, Poo C, Isaacson JS (2012) Cortical feedback control of olfactory bulb circuits. Neuron 76:1161-1174. CrossRef Medline

Burton SD (2017) Inhibitory circuits of the mammalian main olfactory bulb. J Neurophysiol 118:2034-2051. CrossRef Medline

Caputi A, Rozov A, Blatow M, Monyer H (2009) Two calretinin-positive GABAergic cell types in layer $2 / 3$ of the mouse neocortex provide different forms of inhibition. Cereb Cortex 19:1345-1359. CrossRef Medline

Carleton A, Petreanu LT, Lansford R, Alvarez-Buylla A, Lledo PM (2003) Becoming a new neuron in the adult olfactory bulb. Nat Neurosci 6:507518. CrossRef Medline

De Marchis S, Bovetti S, Carletti B, Hsieh YC, Garzotto D, Peretto P, Fasolo A, Puche AC, Rossi F (2007) Generation of distinct types of periglomerular olfactory bulb interneurons during development and in adult mice: implication for intrinsic properties of the subventricular zone progenitor population. J Neurosci 27:657-664. CrossRef Medline

Dieni CV, Panichi R, Aimone JB, Kuo CT, Wadiche JI, Overstreet-Wadiche L (2016) Low excitatory innervation balances high intrinsic excitability of immature dentate neurons. Nat Commun 7:11313. CrossRef Medline

Espósito MS, Piatti VC, Laplagne DA, Morgenstern NA, Ferrari CC, Pitossi FJ, Schinder AF (2005) Neuronal differentiation in the adult hippocampus recapitulates embryonic development. J Neurosci 25:10074-10086. CrossRef Medline

Fernández ME, Croce S, Boutin C, Cremer H, Raineteau O (2011) Targeted electroporation of defined lateral ventricular walls: a novel and rapid method to study fate specification during postnatal forebrain neurogenesis. Neural Dev 6:13. CrossRef Medline

Fiorelli R, Azim K, Fischer B, Raineteau O (2015) Adding a spatial dimension to postnatal ventricular-subventricular zone neurogenesis. Development 142:2109-2120. CrossRef Medline

Fogli Iseppe A, Pignatelli A, Belluzzi O (2016) Calretinin-periglomerular interneurons in mice olfactory bulb: cells of few words. Front Cell Neurosci 10:231. CrossRef Medline

Fukunaga I, Berning M, Kollo M, Schmaltz A, Schaefer AT (2012) Two distinct channels of olfactory bulb output. Neuron 75:320-329. CrossRef Medline 
Fukunaga I, Herb JT, Kollo M, Boyden ES, Schaefer AT (2014) Independent control of gamma and theta activity by distinct interneuron networks in the olfactory bulb. Nat Neurosci 17:1208-1216. CrossRef Medline

Ge S, Yang CH, Hsu KS, Ming GL, Song H (2007) A critical period for enhanced synaptic plasticity in newly generated neurons of the adult brain. Neuron 54:559-566. CrossRef Medline

Geramita M, Urban NN (2017) Differences in glomerular-layer-mediated feedforward inhibition onto mitral and tufted cells lead to distinct modes of intensity coding. J Neurosci 37:1428-1438. CrossRef Medline

Gire DH, Schoppa NE (2009) Control of on/off glomerular signaling by a local GABAergic microcircuit in the olfactory bulb. J Neurosci 29:1345413464. CrossRef Medline

Gracia-Llanes FJ, Crespo C, Blasco-Ibáñez JM, Nacher J, Varea E, RoviraEsteban L, Martínez-Guijarro FJ (2010) GABAergic basal forebrain afferents innervate selectively GABAergic targets in the main olfactory bulb. Neuroscience 170:913-922. CrossRef Medline

Grubb MS, Nissant A, Murray K, Lledo PM (2008) Functional maturation of the first synapse in olfaction: development and adult neurogenesis. J Neurosci 28:2919-2932. CrossRef Medline

Hayar A, Karnup S, Ennis M, Shipley MT (2004) External tufted cells: a major excitatory element that coordinates glomerular activity. J Neurosci 24:6676-6685. CrossRef Medline

Katagiri H, Pallotto M, Nissant A, Murray K, Sassoè-Pognetto M, Lledo PM (2011) Dynamic development of the first synapse impinging on adultborn neurons in the olfactory bulb circuit. Neural Syst Circuits 1:6. CrossRef Medline

Kohwi M, Petryniak MA, Long JE, Ekker M, Obata K, Yanagawa Y, Rubenstein JL, Alvarez-Buylla A (2007) A subpopulation of olfactory bulb GABAergic interneurons is derived from Emx1- and Dlx5/6-expressing progenitors. J Neurosci 27:6878-6891. CrossRef Medline

Kosaka K, Kosaka T (2007) Chemical properties of type 1 and type 2 periglomerular cells in the mouse olfactory bulb are different from those in the rat olfactory bulb. Brain Res 1167:42-55. CrossRef Medline

Lepousez G, Nissant A, Lledo PM (2015) Adult neurogenesis and the future of the rejuvenating brain circuits. Neuron 86:387-401. CrossRef Medline

Li L, Sultan S, Heigele S, Schmidt-Salzmann C, Toni N, Bischofberger J (2017) Silent synapses generate sparse and orthogonal action potential firing in adult-born hippocampal granule cells. eLife 6:e23612. CrossRef Medline

Li X, Sun C, Lin C, Ma T, Madhavan MC, Campbell K, Yang Z (2011) The transcription factor $\mathrm{Sp} 8$ is required for the production of parvalbuminexpressing interneurons in the olfactory bulb. J Neurosci 31:8450-8455. CrossRef Medline

Livneh Y, Adam Y, Mizrahi A (2014) Odor processing by adult-born neurons. Neuron 81:1097-1110. CrossRef Medline

Maher BJ, Westbrook GL (2008) Co-transmission of dopamine and GABA in periglomerular cells. J Neurophysiol 99:1559-1564. CrossRef Medline

McQuiston AR, Katz LC (2001) Electrophysiology of interneurons in the glomerular layer of the rat olfactory bulb. J Neurophysiol 86:1899-1907. CrossRef Medline

Metzger F, Repunte-Canonigo V, Matsushita S, Akemann W, Diez-Garcia J, Ho CS, Iwasato T, Grandes P, Itohara S, Joho RH, Knöpfel T (2002) Transgenic mice expressing a $\mathrm{pH}$ and $\mathrm{Cl}^{-}$sensing yellow-fluorescent protein under the control of a potassium channel promoter. Eur J Neurosci 15:40-50. CrossRef Medline

Murphy GJ, Darcy DP, Isaacson JS (2005) Intraglomerular inhibition: signaling mechanisms of an olfactory microcircuit. Nat Neurosci 8:354-364. CrossRef Medline

Najac M, De Saint Jan D, Reguero L, Grandes P, Charpak S (2011) Monosynaptic and polysynaptic feed-forward inputs to mitral cells from olfactory sensory neurons. J Neurosci 31:8722-8729. CrossRef Medline
Najac M, Sanz Diez A, Kumar A, Benito N, Charpak S, De Saint Jan D (2015) Intraglomerular lateral inhibition promotes spike timing variability in principal neurons of the olfactory bulb. J Neurosci 35:4319-4331. CrossRef Medline

Ninkovic J, Mori T, Götz M (2007) Distinct modes of neuron addition in adult mouse neurogenesis. J Neurosci 27:10906-10911. CrossRef Medline

Overstreet LS, Hentges ST, Bumaschny VF, de Souza FS, Smart JL, Santangelo AM, Low MJ, Westbrook GL, Rubinstein M (2004) A transgenic marker for newly born granule cells in dentate gyrus. J Neurosci 24:3251-3259. CrossRef Medline

Panzanelli P, Fritschy JM, Yanagawa Y, Obata K, Sassoè-Pognetto M (2007) GABAergic phenotype of periglomerular cells in the rodent olfactory bulb. J Comp Neurol 502:990-1002. CrossRef Medline

Parrish-Aungst S, Shipley MT, Erdelyi F, Szabo G, Puche AC (2007) Quantitative analysis of neuronal diversity in the mouse olfactory bulb. J Comp Neurol 501:825-836. CrossRef Medline

Qin S, Ware SM, Waclaw RR, Campbell K (2017) Septal contributions to olfactory bulb interneuron diversity in the embryonic mouse telencephalon: role of the homeobox gene Gsx2. Neural Dev 12:13. CrossRef Medline

Sanz Diez A, Najac M, De Saint Jan D (2017) Basal forebrain control of olfactory bulb interneurons. bioRxiv 216259. Advance online publication. Retrieved from Nov. 8, 2017. doi: 10.1101/216259.

Sawada M, Kaneko N, Inada H, Wake H, Kato Y, Yanagawa Y, Kobayashi K, Nemoto T, Nabekura J, Sawamoto K (2011) Sensory input regulates spatial and subtype-specific patterns of neuronal turnover in the adult olfactory bulb. J Neurosci 31:11587-11596. CrossRef Medline

Shao Z, Puche AC, Liu S, Shipley MT (2012) Intraglomerular inhibition shapes the strength and temporal structure of glomerular output. J Neurophysiol 108:782-793. CrossRef Medline

Shao Z, Puche AC, Shipley MT (2013) Intraglomerular inhibition maintains mitral cell response contrast across input frequencies. J Neurophysiol 110:2185-2191. CrossRef Medline

Smith TC, Jahr CE (2002) Self-inhibition of olfactory bulb neurons. Nat Neurosci 5:760-766. CrossRef Medline

Spampanato J, Sullivan RK, Turpin FR, Bartlett PF, Sah P (2012) Properties of doublecortin expressing neurons in the adult mouse dentate gyrus. PLoS One 7:e41029. CrossRef Medline

Srinivas S, Watanabe T, Lin CS, William CM, Tanabe Y, Jessell TM, Costantini F (2001) Cre reporter strains produced by targeted insertion of EYFP and ECFP into the ROSA26 locus. BMC Dev Biol 1:4. CrossRef Medline

Tiveron MC, Beclin C, Murgan S, Wild S, Angelova A, Marc J, Coré N, de Chevigny A, Herrera E, Bosio A, Bertrand V, Cremer H (2017) Zicproteins are repressors of dopaminergic forebrain fate in mice and $C$. elegans. J Neurosci 37:10611-10623. CrossRef Medline

Toni N, Schinder AF (2015) Maturation and functional integration of new granule cells into the adult hippocampus. Cold Spring Harb Perspect Biol 8:a018903. CrossRef Medline

Waclaw RR, Allen ZJ 2nd, Bell SM, Erdélyi F, Szabó G, Potter SS, Campbell K (2006) The zinc finger transcription factor Sp8 regulates the generation and diversity of olfactory bulb interneurons. Neuron 49:503-516. CrossRef Medline

Weinandy F, Ninkovic J, Götz M (2011) Restrictions in time and space: new insights into generation of specific neuronal subtypes in the adult mammalian brain. Eur J Neurosci 33:1045-1054. CrossRef Medline

Whitman MC, Greer CA (2007) Adult-generated neurons exhibit diverse developmental fates. Dev Neurobiol 67:1079-1093. CrossRef Medline 